الإعجاز التشريعي في الزكاة

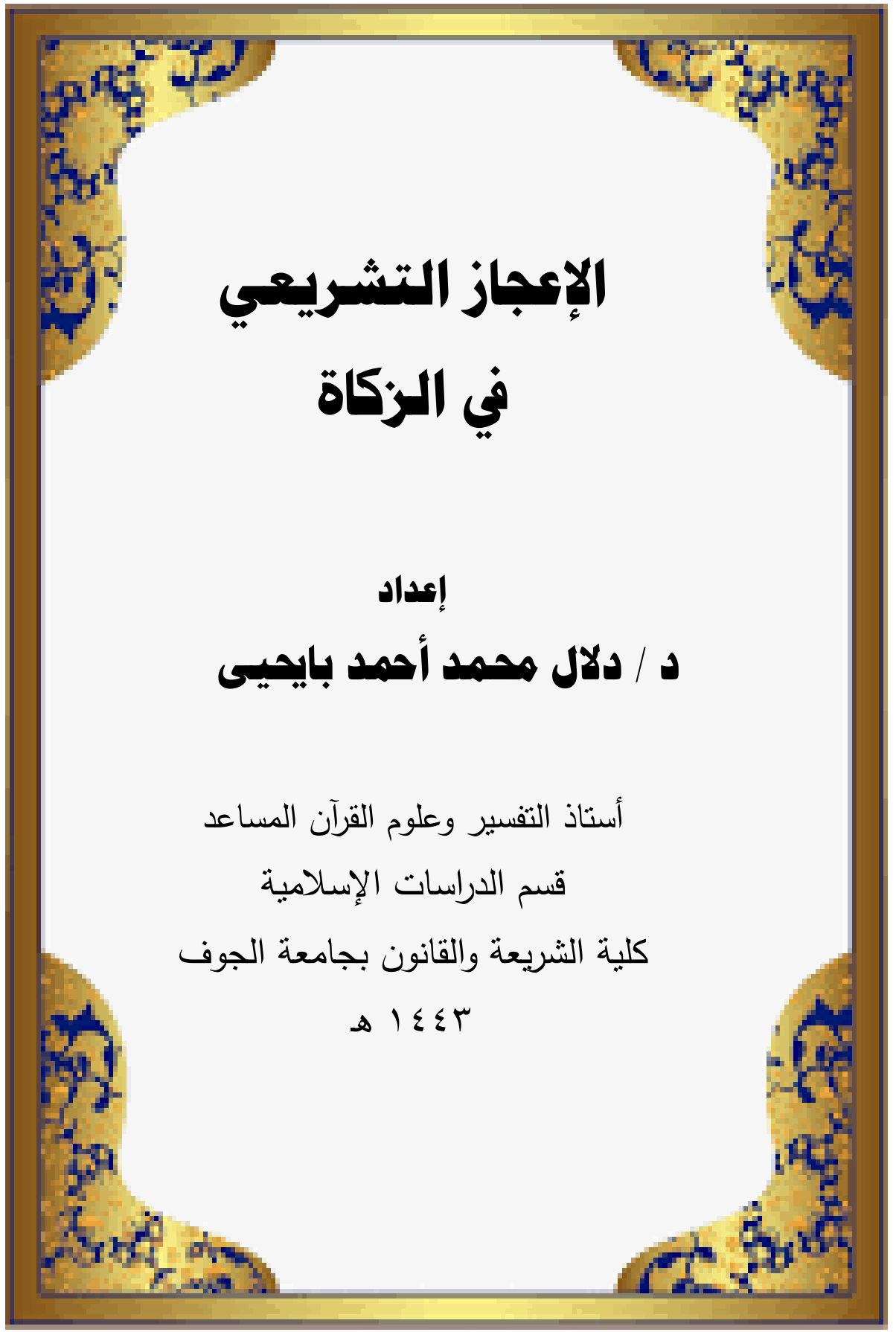

\title{
I YYA
}

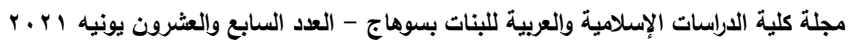


الإعجاز التشريعي في الزكاة 


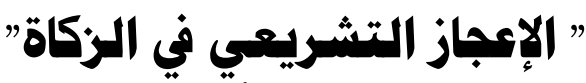 \\ دلال محمد أحمد بايحيى.}

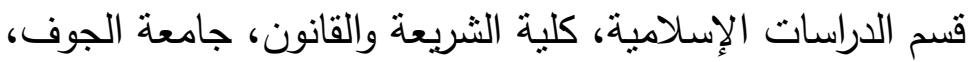

سكاكا، المملكة العربية السعودية.

\section{البريد الإلكتروني: dmbayahya@ju.edu.sa}

هذا البحث من الموضوعات المهمة في الثريعة الإسلامية حيث إنه

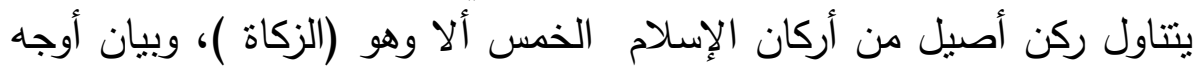

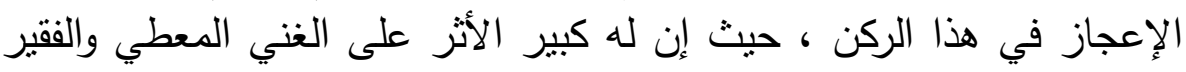

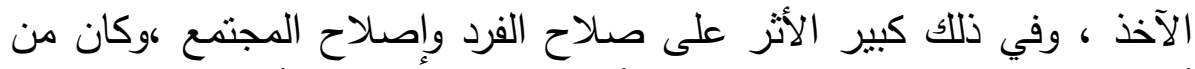

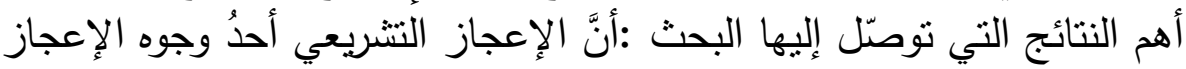

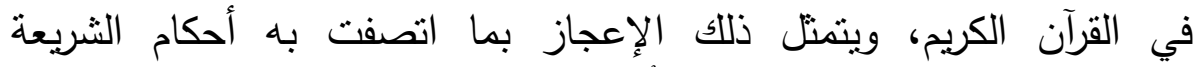

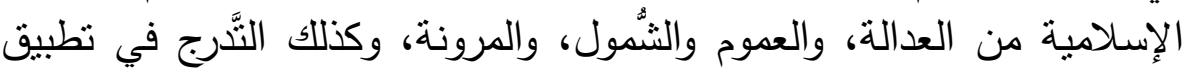

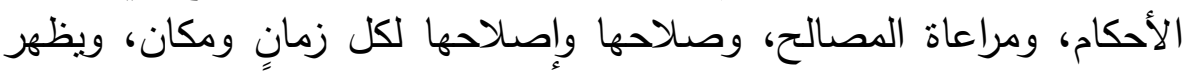
كل ذلك جليًا عند مقارنتها بالقوانين الوضعية الحديثة التي هي من صنع التِ

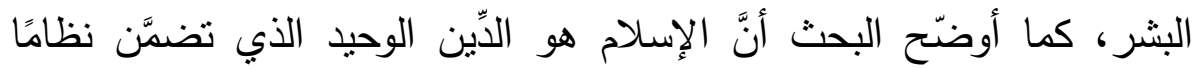

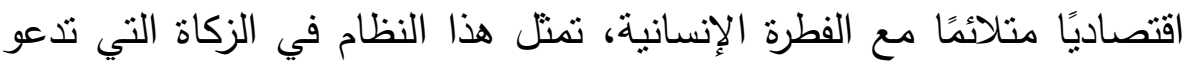

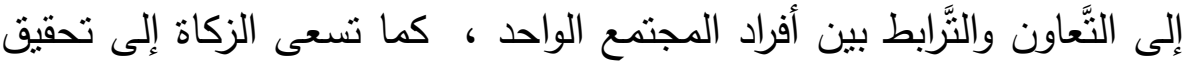

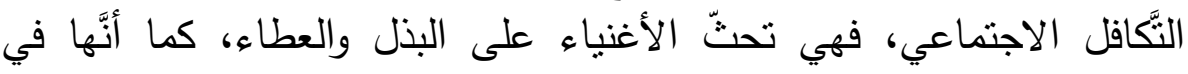
الوقت ذاته تسعى لتجفيف منابع الحسد والبغضاء في نفوس الفقراء، وتدعوهم

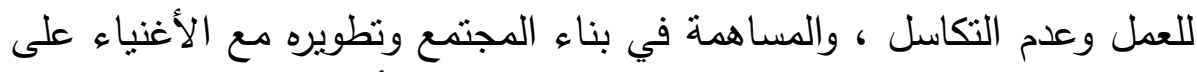

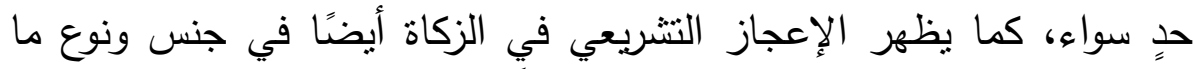

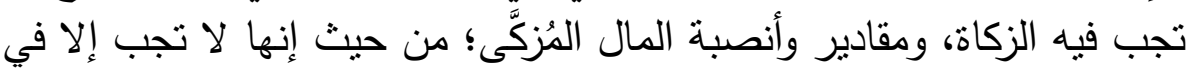

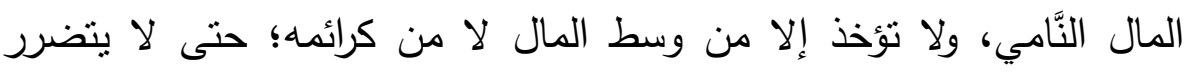

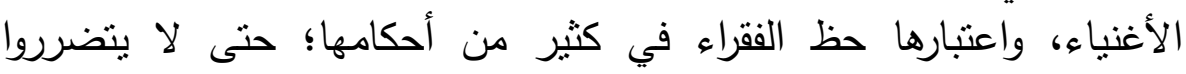
وتحصل مواساتهم وإعانتهم.

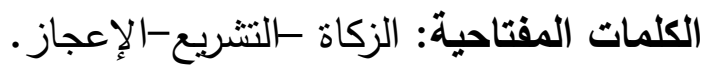




$$
\text { الإعجاز التشريعي في الزكاة }
$$

\section{Legislative miracle in zakat}

\section{Dalal Mohammed Ahmed Bayhi.}

Department of Islamic Studies, Faculty of Sharia and Law, Al-Jouf University, Skaka, Saudi Arabia.

E-mail: dmbayahya@ju.edu.sa

\section{Abstract:}

This research is one of the important topics in Islamic law, as it deals with an authentic corner of Islam, namely zakat, and the statement of miracles in this corner, since it has a great impact on the rich and the poor who are taking, and in this it has a great impact on the goodness of the individual and the reform of society،

One of the most important findings of the research was that legislative miracles are one of the miracles in the Qur'an, and this miracle is the justice, general and inclusiveness of the provisions of Islamic law, as well as the gradual application of provisions, consideration of interests, validity and reform for every time and place, all of which is evident when compared to modern positive laws that are man-made, and hatred in the hearts of the poor It invites them to work and not to be laziness, and to contribute to the building and development of society with the rich alike, as the legislative miracle in zakat also shows in a race and type in which zakat is levied, and the amounts and shares of money that are wheeded; in that they are only answered in developing money, and are taken only from the middle of the money rather than as their patrons; so that the rich are not affected, and consider the luck of the poor in many of its provisions; so that they are not harmed, comforted and supported.

Keywords: Zakat - Legislation - Miracle. 


\section{المقدهمـــة}

الحمد لله الحكيم العليم، أنزل كتابه بالعدل في الأحكام وهو العليّ

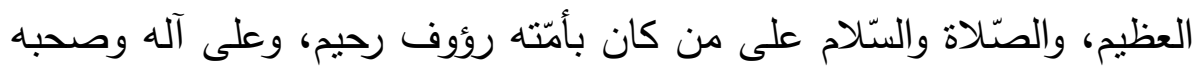

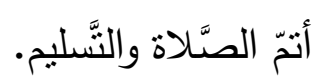

$$
\text { أمّا بعد }
$$

فقد جاء ديننا الإسلاميّ الحنيف بشريعةٍ وافيةٍ عظيمة لا مثيل لها،

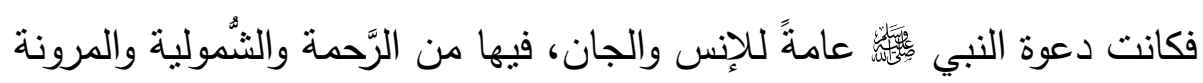

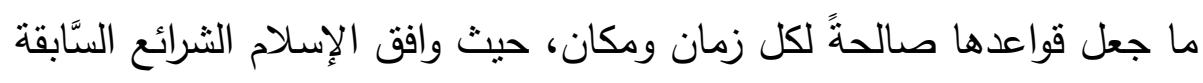

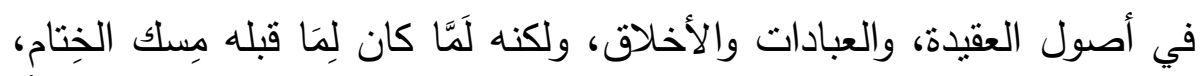

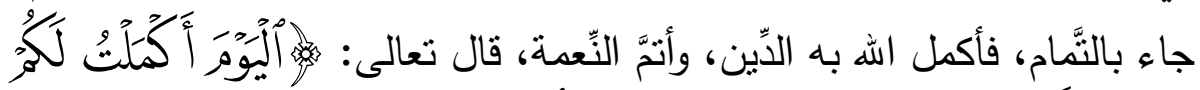

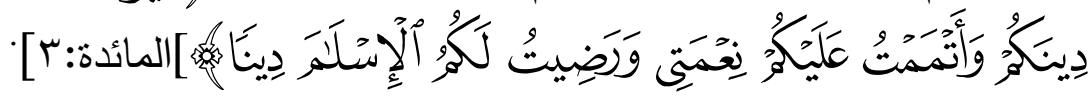

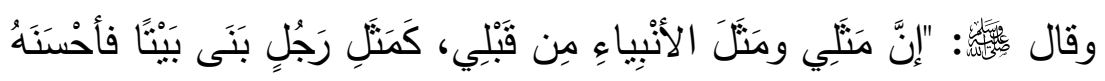

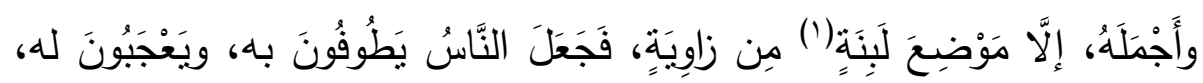

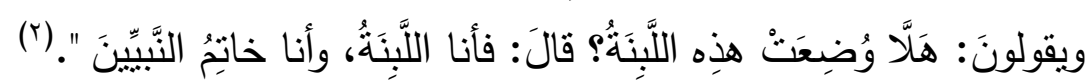

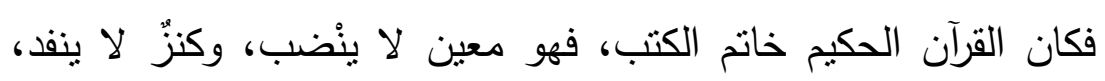

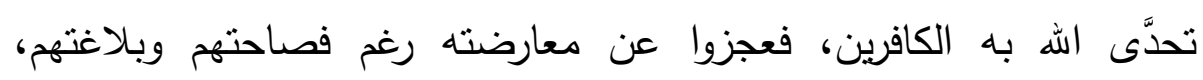
وأصبحوا من الخاسرين.

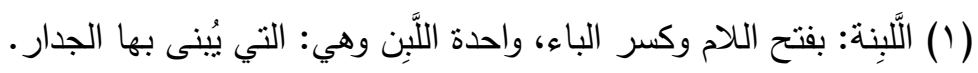

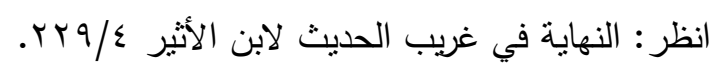

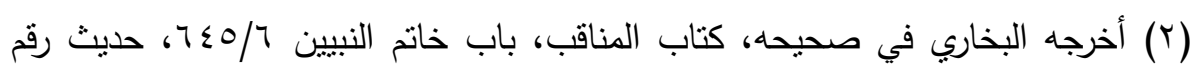

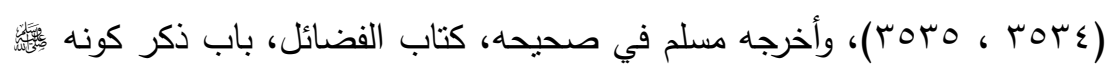

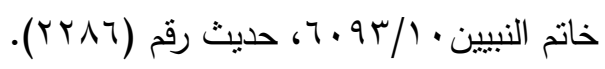


وقد تتافس أُولوا الألباب في معرفة أسرار الكتاب، وبرعوا في استخراج علومه واستتباط أحكامه فكان عبرةً وهداية، ومعجزةً للخلق وآية.

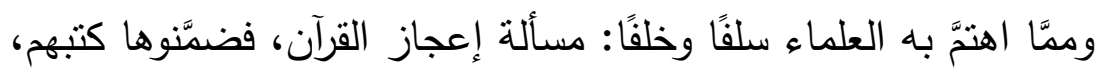
وأودعوها بطون مصنفاتهم، ومن أبرز من أفردها بالتأليف:

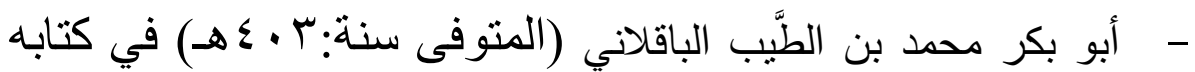
(إعجاز القرآن).

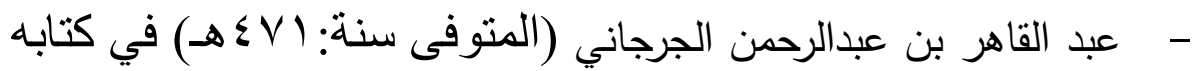

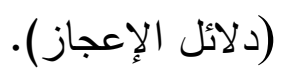

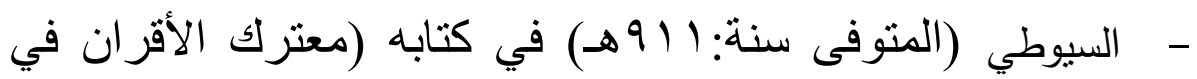
إعجاز القرآن).

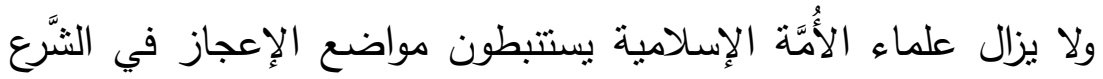

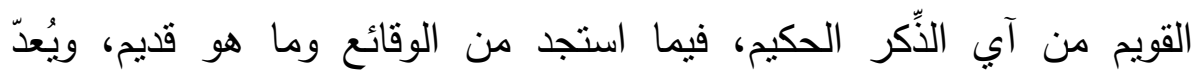

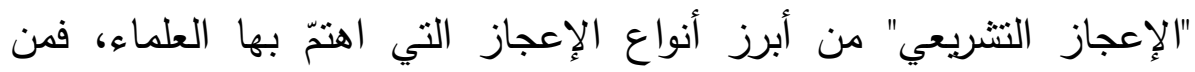

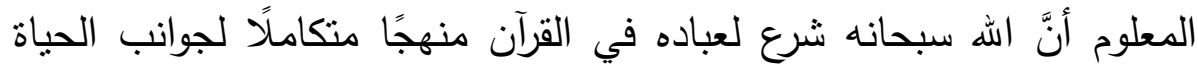

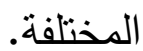

ومن توفيق اله تعالى لي أن أكرمني في هذا البحث بدراسة "الإعجاز

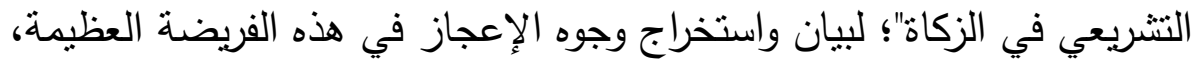

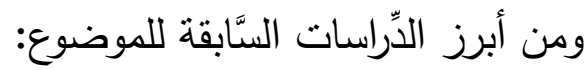
- الإعجاز التشريعي في الزكاة) أ.د رفعت السَّيد العوضي، وهي دراسة اقتصرت على وعاء الزكاة (') فقط.

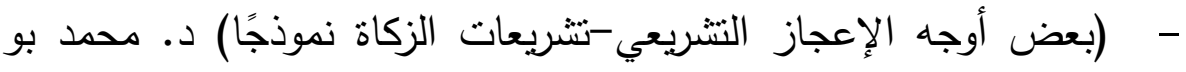
رباب، وهي دراسة تختص بالإعجاز الاقتصادي للزكاة فقط.

( (1)الوعاء الزَّكوي هو: النّّـاب أو الـقدار الذي تجب به الزكاة عند توافره، وقيل: وعاء الزكاة مصطلح يقصد به الأموال التي تجب فيها الزكاة.انظر : صل التهاة من الكتاب. 
- أوجه الإعجاز التشربعي في الزكاة جمع ودراسة) د. بدرية الثَّربف، وهي

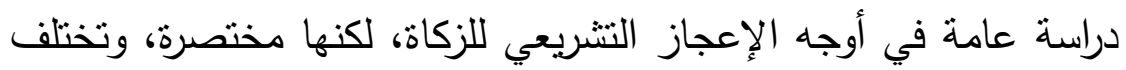
تمامًا عن هدف هذا البحث. وقد اتَّبعت في هذه الدِّراسة: المنهج الاستقرائي والتَّليلي، ومما شجعني على هدي اختيار هذا الموضوع ما تميَّز به من الأهمية البالغة من حيث:

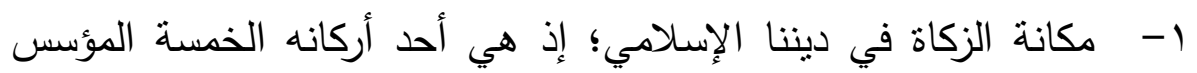
عليها، ثم إنها متعلقة بكثير من الأحكام والأنصبة التي ينبني على الإسي الته المسلم معرفتها. r- مكانة الإعجاز النتريعي، وأهميته في المكتبة الإسلامية عمومًا، وفي علوم القرآن خصوصًا. r- ما تضمنه الإعجاز التشريعي للزكاة من فوائد فريدة، وآثار عجيية على الغني والفقير من جهة، وعلى المال من جهةٍ أخرى، وعلى المجتمع بصورة عامة، ودوره في تحقيق التَّاحم والثَّاصل بين أبناء الجسد الواحد، ونشر الألفة والمحبة بينهم.

وقد اقتضى العمل في هذا البحث تقسيم الخطة إلى: مقدمة، وتمهيد، وخمسة مطالب، وخاتمة.

أمَّا المقدمة فحوت نبذة عن أهمية الموضوع، وأسباب اختياره، وخطة البحث، وحه، ومنهجي فيه.

ثم التمهيد: وفيه الحديث عن الإعجاز التشريعي. ثم المطلب الأول: وتضمَّن الإعجاز النشربعي في الزكاة. يليه المطلب الثاني: أثز الزكاة على الغني "المعطي". المطلب الثالث: أثز الزكاة على الفقير "المتلقي". المطلب الرابع: أثز الزكاة على المال. 
المطلب الخامس: أثز الزكاة على المجتمع. الخاتمة: وذكرت فيها أهم النتائج التي توصلت إليها من خلال البحث. ثم الفهارس العلمية، وتشنمل: - - فهرس المصادر والمراجع. - هزرس الموضوعات. أها مندهمي في البمث، فقد سرت على النهو التالي: ا- عزوت الآيات إلى مواضعها من القرآن، ببيان رقم الآية واسم السورة، مع الالنزام بكتابة الآيات وفق الرسم العثماني، واعتمدت في ذلك على مصحف المدينة النَّبَيَّة. r- خرجت الأحاديث النبوية الواردة في ثنايا البحث من الكتب المعتمدة في ذلك.

r- قدمت للموضوع بتمهيد، وفيه دراسة موجزة عن الإعجاز التشريعي. ع - عقت مقارنة بين النظام الرأسمالي، والنظام الاشتتراكي والنتريع الإسلامي الخالد؛ ليظهر مدى إعجاز النشريع الإسلامي، فبضدها تثبيَّن الأثباء.

وأخيرًا، أسأل الله العظيم، أن يجعل عملي خالصًا، وينفع به في الدارين، والحمد لله رب العالمين.

* $\quad * \quad * \quad * \quad * \quad *$ 


\section{تمهـداد}

\section{التهريف بالإعباز التشربهي.}

\section{أولاً: المعنى اللغوي: \\ (أ) الإعجاز في اللغة: الامبي:}

الإعجاز: مصدر الرباعي (أعجز)، وأعجزه: جعله عاجزًا، والعَجْز :

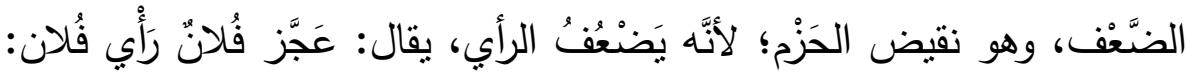

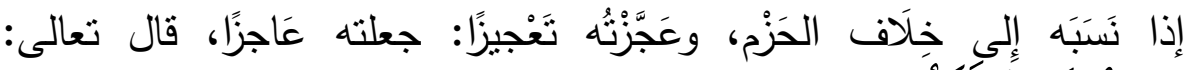

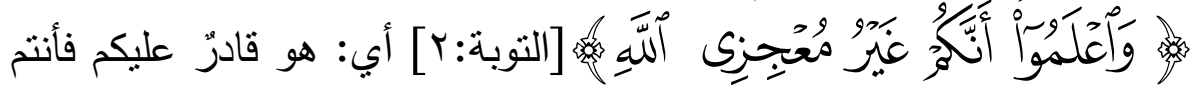

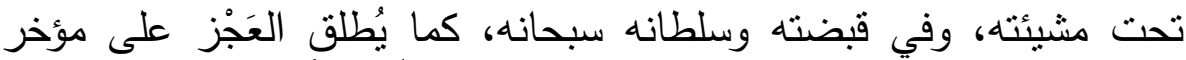

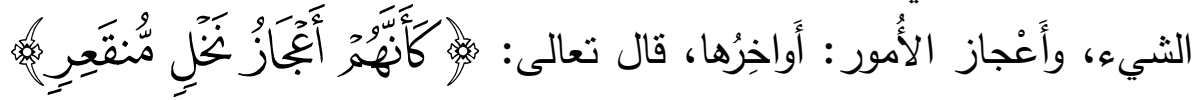

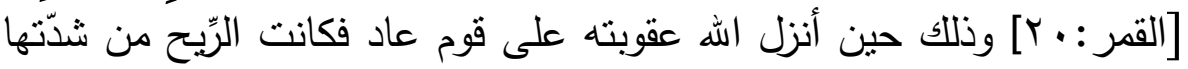

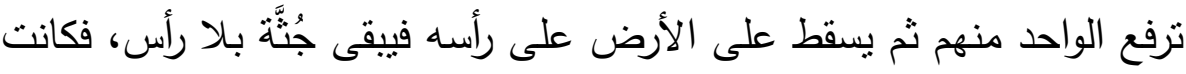

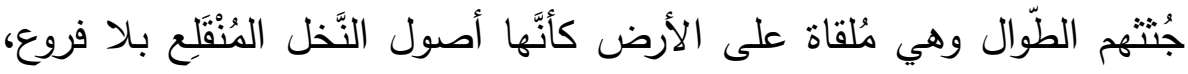

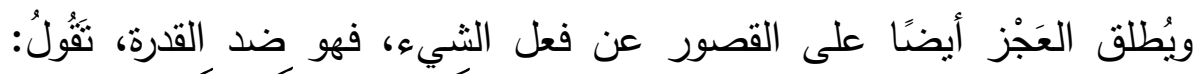

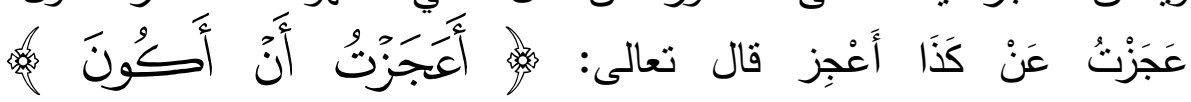

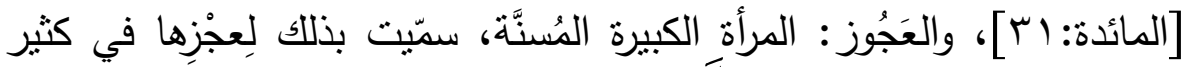

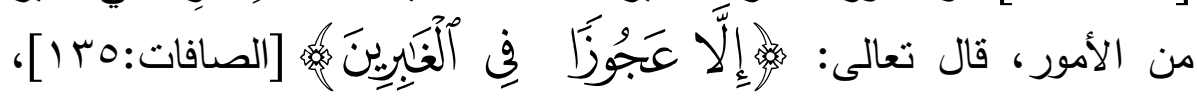

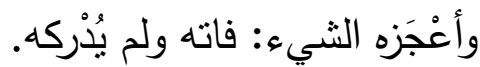

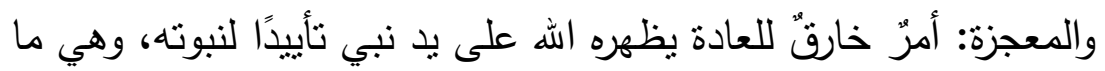

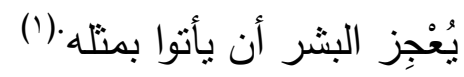

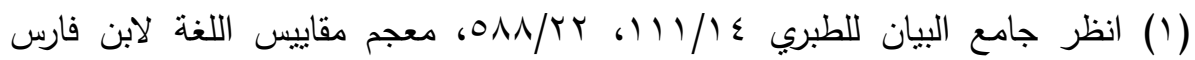

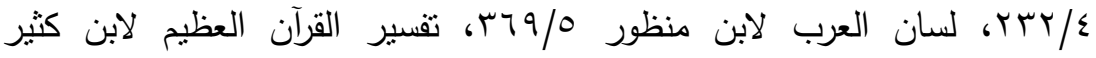

$$
. \varepsilon \vee 9 / 1 \cdot r \cdot r / \varepsilon
$$




\section{(ب) الشَرع في اللغة:}

الثَرَعَ: شيءٌ يُفتح في امتدادٍ يكون فيه، ومن ذلك: الثَّريعة؛ فهي تُطلق على مورد الماء الذي يُقصد للثُرب، ثم استعملها العرب في الطريقة المستقيمة؛

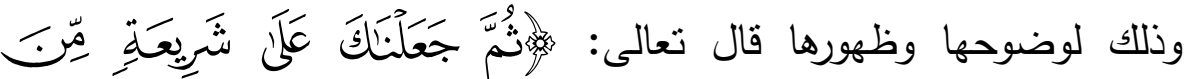

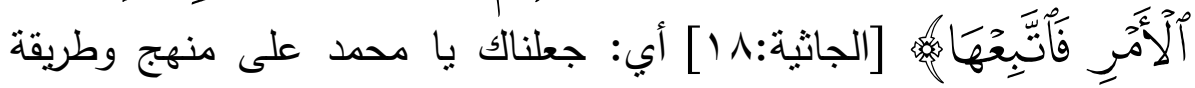
وسنة sن أرسلنا قبلك من رسلنا عليهم الصلاة والسلام. والثَّربعة والثَّرائع: ما شرع الله للعباد من أمر الدين، وأمرهم بالتمسك به.

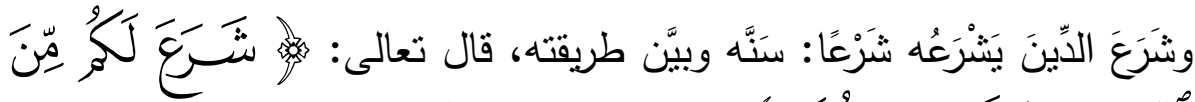

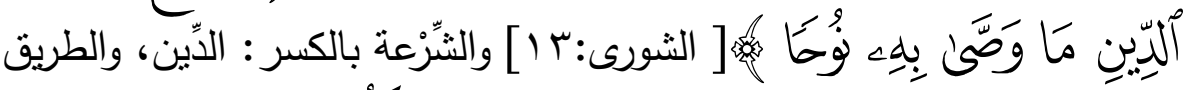

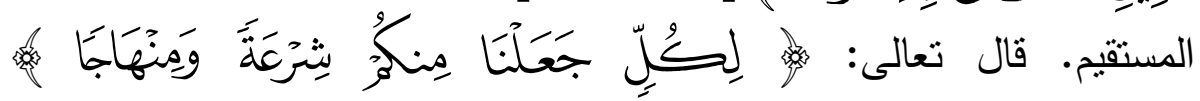
[ المائدة:^^] والمعنى كما رُوي عن ابن عباس رضي الله عنهما وغيره أي: سبيلًا وطريقًا وسُنَّة. وأيضًا يُطلق الثََّّع في اللغة بمعنى: السَّواء، يقال: نحن في هذا شرَعْ:

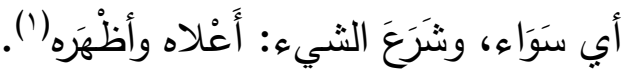

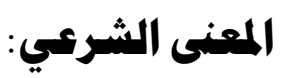
ذكر العلماء عدة تعريفات للإعجاز التشريعي، ومن ذلك: أنَّه: تشريعات القرآن ونُظمه ومناهجه، والمبادئ التي قرَّرها، والقيم التي دعا إليها، والأسس التي أرْساها، والهداية التي هدف إليها، وقد بَتَغَ هذا التشريع

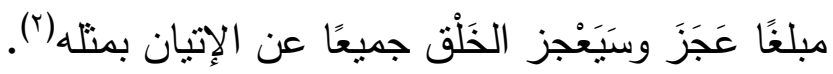

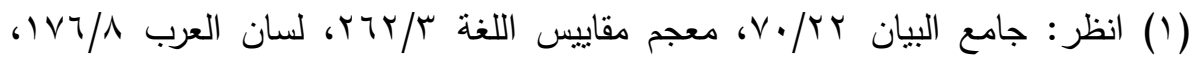

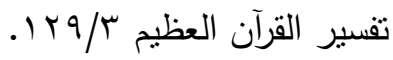

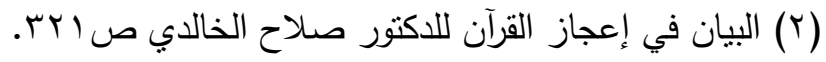




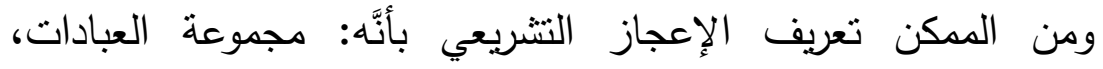
والأحكام والمعاملات التي جاءت بها الشريعة الإسلامية متتاسبة مع الفطرة

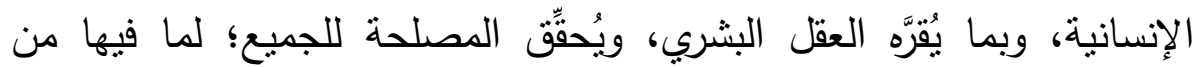

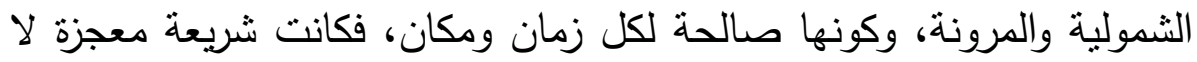

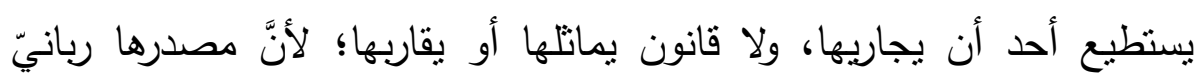
تنزيلٌ من حكيةٍ حميد.

\section{أهمية الإعجاز التشريعي.}

لقد اكتسبت نصوص الثريعة الإسلامية - بما فيها من هداية إلى سبيل الحق والرشاد، ومحاربة للهام والفساد-من المرونة والعموم ما جعلها تساير عوامل النمو والبناء، وتقود الحضارة الإنسانية إلى التقام والارتقاء. فينتج من تطبيقها على الناس أُمَّة متكاملة، متميزة عن سائر الأمم. قال

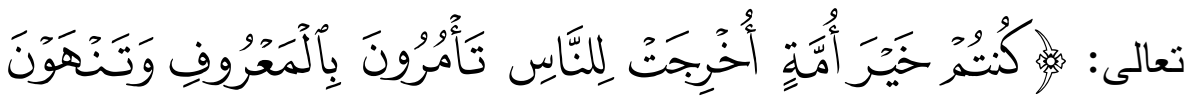

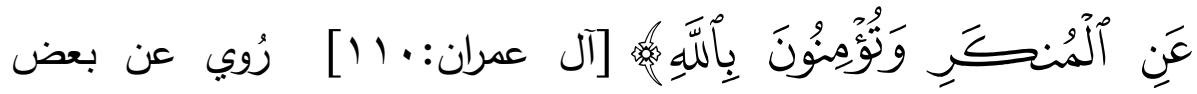
الصحابة رضي الله عنهم والمفسرين في معنى الآية أي: كنتم خير النَّاس

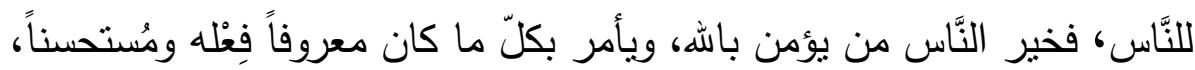

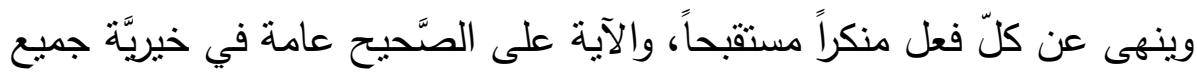
القرون، وإن كان أفضلها قرن الصحابة رضي الله عنهم، ثم من بعدهم. (')

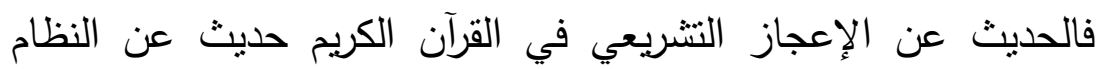
المتقن المرِن الخالد، للكون وما فيه، فلقد تضمن القرآن الكريم تشريعات ومناهج

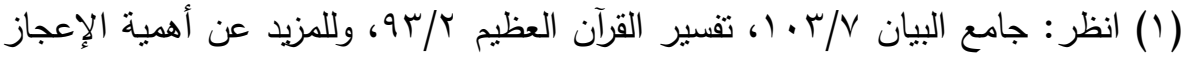

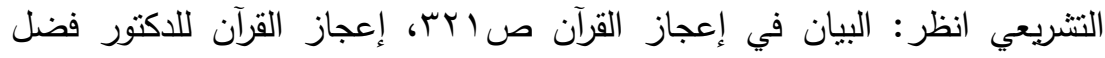

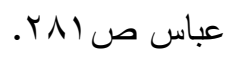




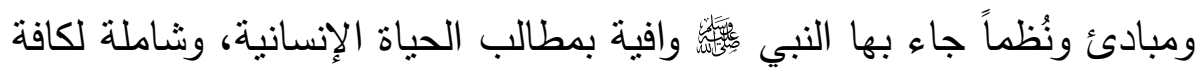
المجالات، سواء حياة الفرد أو حياة المجتمع، وسواء الجانب العقدي، أو العبادي، أو الأخلاقي، أو الاجتماعي، أو السياسي، أو الدولي، أو غير ذلك أو من نواحي الحياة المختلفة. يقول الأستاذ حسن عتُر: "ومما ينوه بجلال النتربع القرآني: أنه نتزل في عصر دامس الجهل، وفي أُمَّة عريقة الأُمََّة، ومع هذا فإنه أمر بكتابة الديون والإشهاد عليها، ورتب أحكامًا للحفاظ على حقوق أصحابها، وهذا هو الإعجاز الذي تحار العقول في معرفة سببه، إلا أنَّها تُشلّم بأنَّه نتزيل العليم الحكيم:

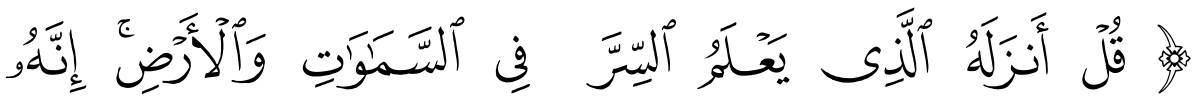

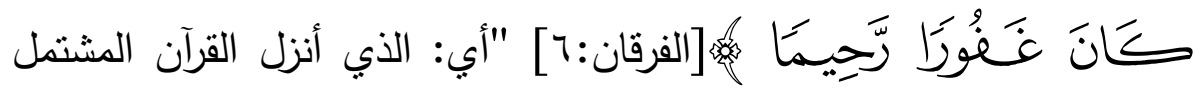
على أخبار الأوَّلّن والآخرين، هو الذي بعلم البواطن كعلمه بالظوَّاهر، ويعلم غيب السموات والأرض، ويعلم ما يُصْلح عباده وما يُفْسدهم، لا تخفى عليه خافية، والسِّر عنده علانية. (')

\section{الأسباب التي جمات التشريع القرآني هن أوجه إعباز القرآن.}

إنَّ من أعظد الأسباب التي جعلت النتربع القرآني من أوجه إعجاز القرآن: الأسس التي قام عليها، والأهداف النبيلة التي سعى إلى تحقيقها في كلِّ ما شرعه، والتي رُوعي فيها حال المخاطبين وما جُبلوا عليه، ممَّا ضمن لهذا التشريع سرعة الاستجابة له، والحرص على تطبيقه، والتمسك به، ومن

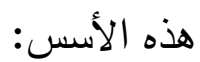

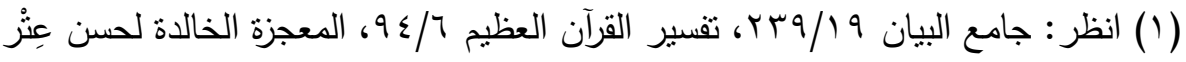
صסץr. 


\section{ا - عدم الحرج.}

وقد عدَّه الفقهاء أصلًا من الأصول التي اعتبرها الثَّارع، واستتبطوا منه أحكامًا كثيرة، فتكاليف الإسلام ليس فيها شيء من الحرج والثنّدة، وكذللك الأحكام الشرعية ليس فيها شيء من العُسر والثَّضيقيق على الناس، والسِّر في التيسير: أنَّ المرجو من تطبيق الثرع إنَّما هو تحصيل المصالح، ودفع المضار، ونيل الأجور، وليس إرهاق العباد بالتكاليف الثنَّاقة؛ التي قد تنؤدي

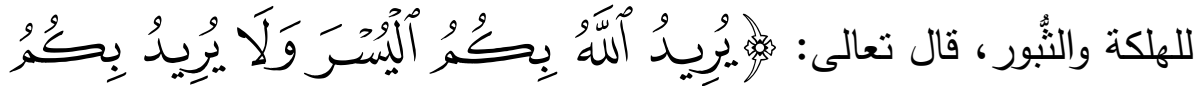

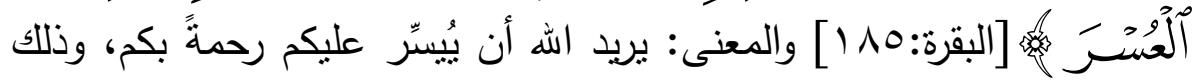

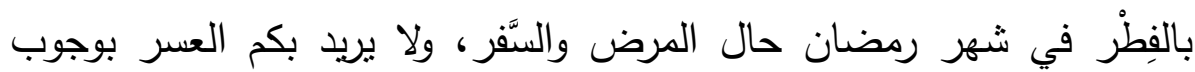

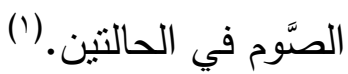

والأدلة على أنَّ هذه الثربعة مبنيةٌ على رفع الحرج كثيرة، منها: قوله

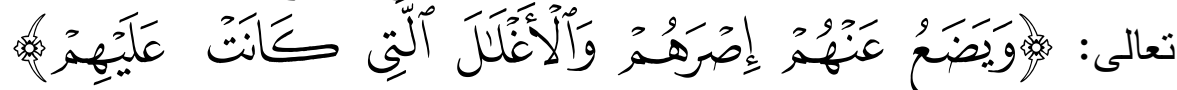

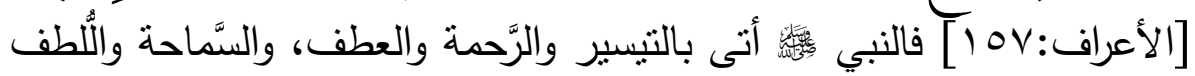
لهذه الأُمَّة ولمن قبلها، فقد كانت الأُمم التي قبلنا، تجد في بعض ما شُرِع لهم

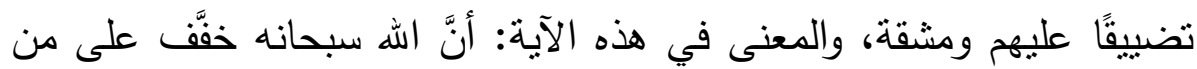
اتبع النبي صلى الله عليه وسلم من أهل الكتاب النَّنديد والمشقة التي كانت في

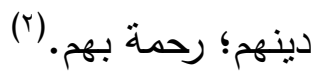

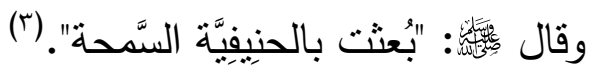

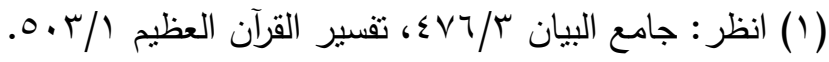

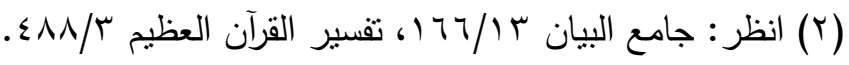

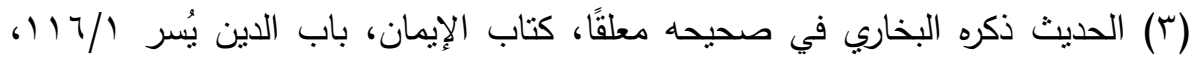

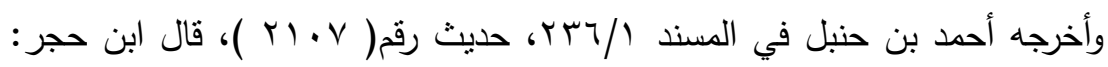

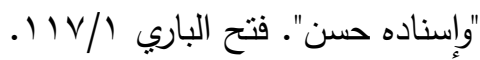


وكذللك حرَّم الله المينتَة، وأباحها عند المخْمَصة، وشَرَع التيمم عند فقد

الماء، والقَصْر في السَّفر ، إلى غير ذلك من الأمثلة. (1)

r- قالة التكاليف

فقد امتازت الثَّربعة الإسلامية عمَّا تقدمها من الثرائع بقلة التَّكاليف

على الثقّلين، كما يظهر في نصوص الوحيين، وحتى لا ينشأ عن كثرتها حرج

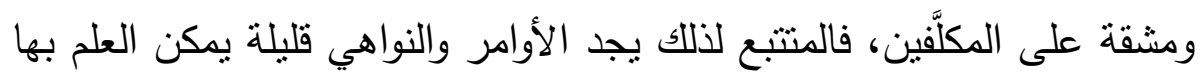

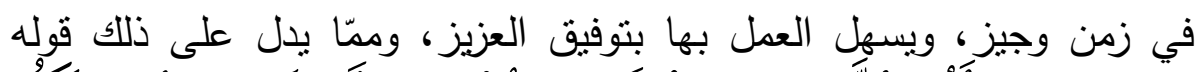
تعالِي:

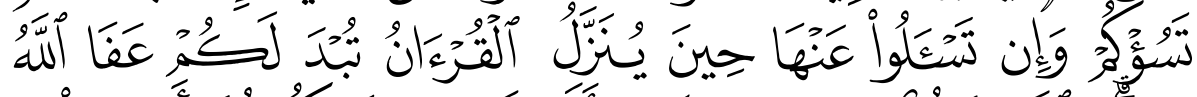

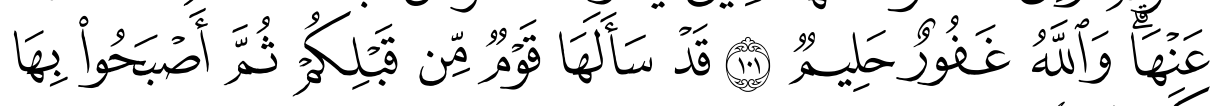

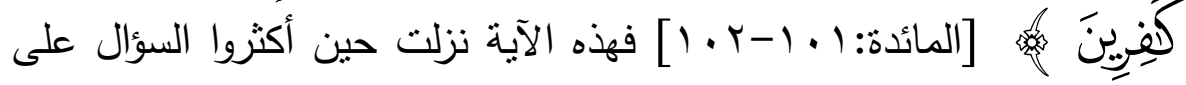
النبي صلى الله عليه وسلم في مسائل مختلفة، ومعنى الآية أي: لا تستأنفوا

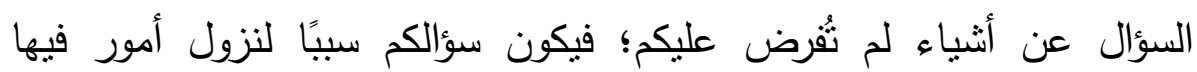

\section{تضييق عليكم وتشديد لا تُطيقونه.}

وقوله بـ

تعتدوها، وحرم أثياء فلا تتتهكوها، وسكت عن أثياء رحمة بكم غير نسيان فلا

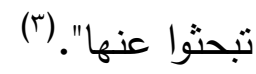

(1) انظر : تاريخ الفقه الإسلامي للسايس ص. ب، تاريخ التشريع الإسلامي لمحد الخضري

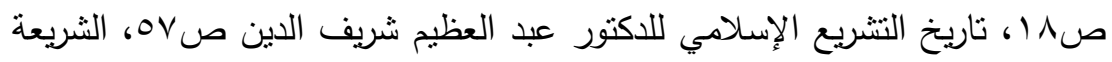

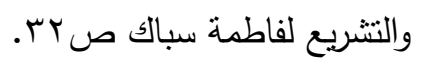

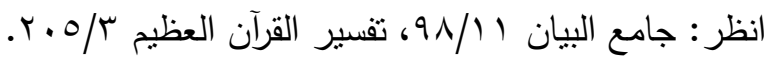

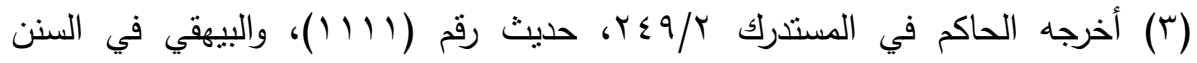

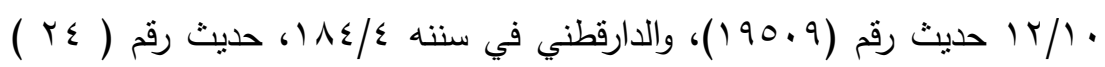

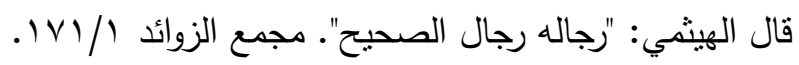




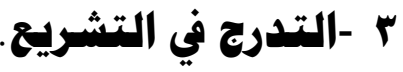

فقد جاء الإسلام والعرب قد استحكمت فيهم عادات كثيرة، فاقتضت

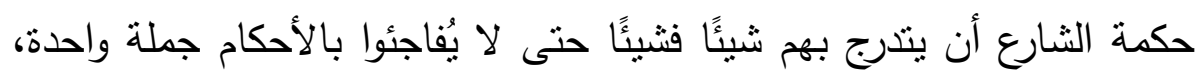
وبترك ما اعتادت عليه نفوسهم فينفروا ويثقل عليهم التطبيق، ومن ذلك: التدرج في تحريم الخمر، وكانت من العادات المستحكمة عندهم، فلم يصرح بداية

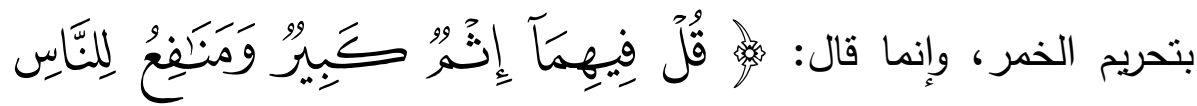

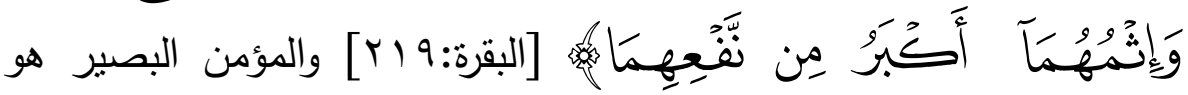
الذي يفهم أنَّ ما كثر إثمه وعظم ضرره فالأولى نركه، ولذلك رُوي عن مجاهد

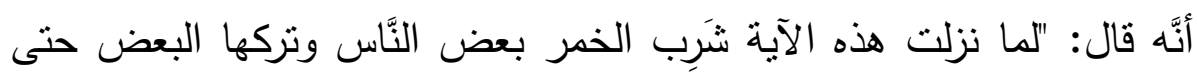
نزل تحريمها".

ثم المرحلة الثانية بأن حرَّم الله سبحانه شرب الخمر وقت الصلاة، قال

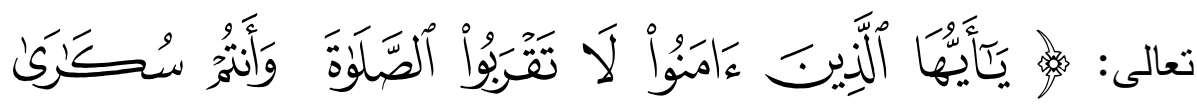

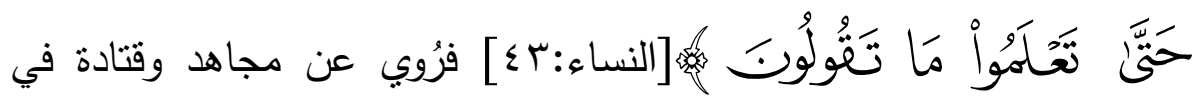
معنى هذه الآية: أنَّهم نُهوا أن يصلُّوا وهم سكارى، فكانوا يجتنبون السُّكر عند إقامة الصلوات ثم نُسِخ بالتَّحريم، فصرح بالنهي عنها تمامًا في قوله تعالى: مَ

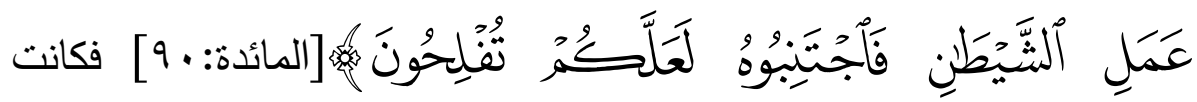
الاستجابة بسمعنا وأطعنا. (1)

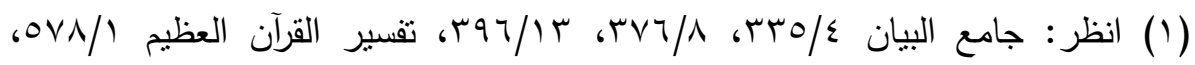

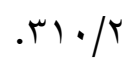




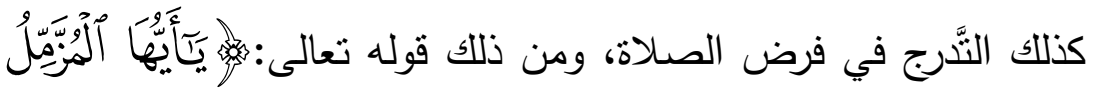

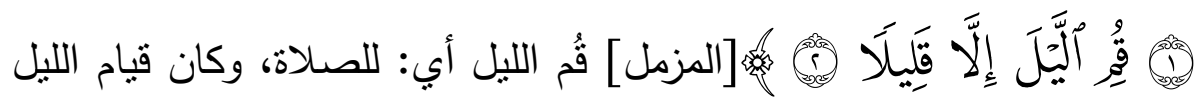

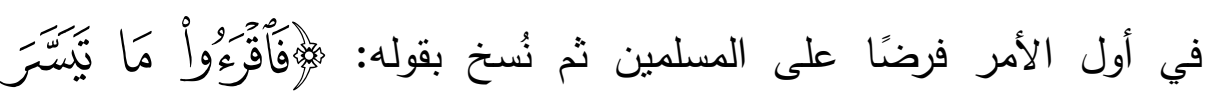

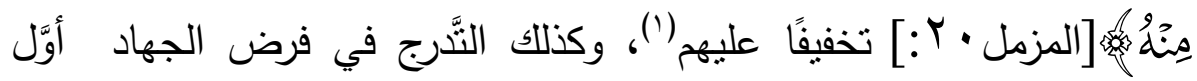

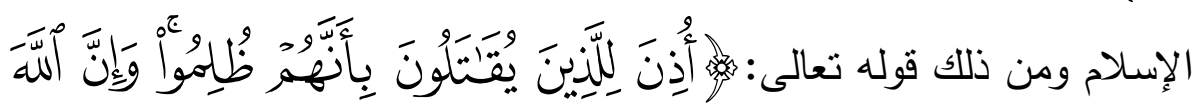

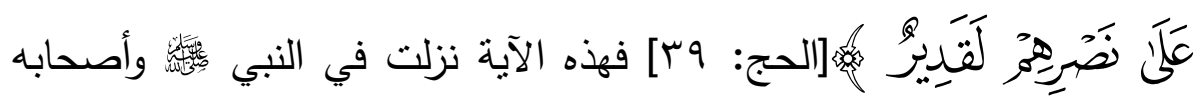
رضي الله عنهم، وهي كما رُوي عن أبي بكر الصِّديق رضي الهُ الهُ عنه وغيره

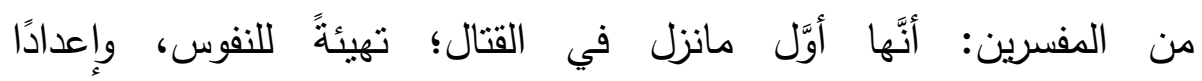

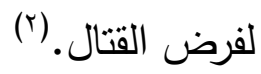
إلى غير ذلك من الأمثلة، فإنَّ هذه الثريعة بُنيت على جلب مصالح

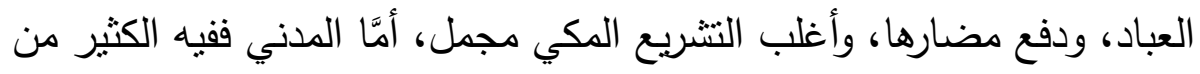

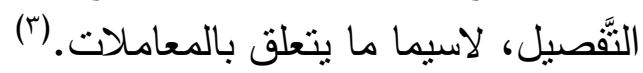

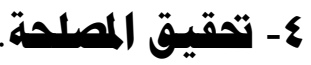

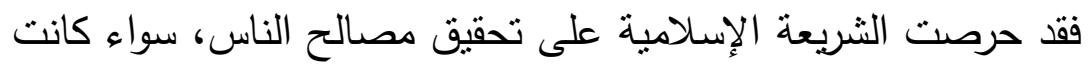

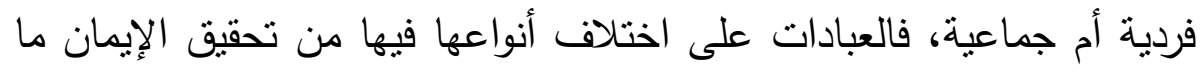

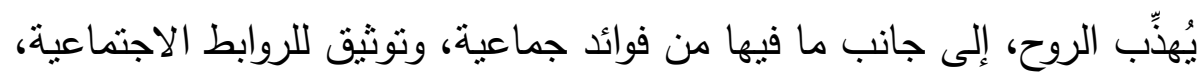

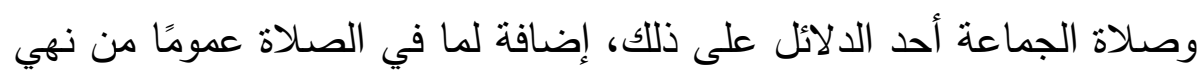

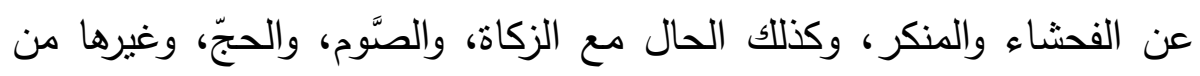

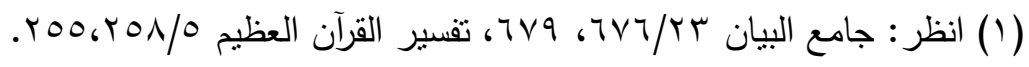

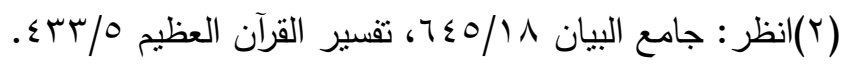

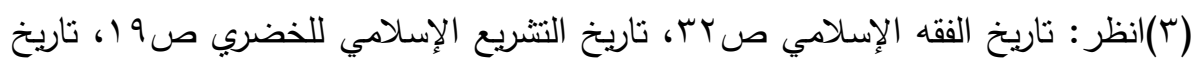

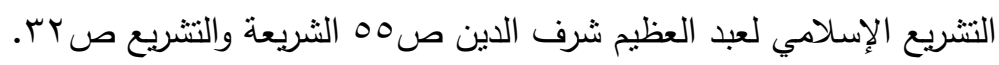


العبادات، سواء كانت فريضة أم نافلة. وأيضًا ما شرعه الله من معاماتلات كان الغرض منه تحقيق المنافع بين الناس، وتبادل المصالح مع حفظ الحقوق للجميع، لذلك نرى الثنّارع الحكيم

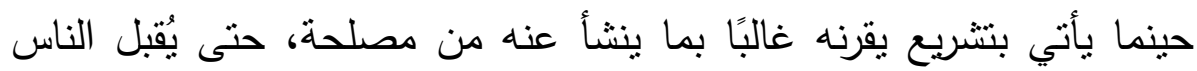

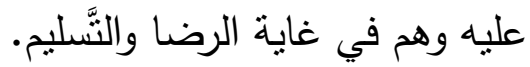
ومن مراعاة هذا الأصل في النتريع: ما نلمسه من نسخ بعض الأحكام

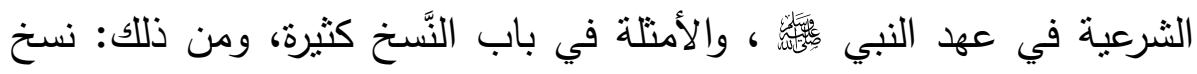
عِدَّة المرأة المتوفى عنها زوجها، فقد كانت تعتدّ حولًا كاملً، قال تعالى

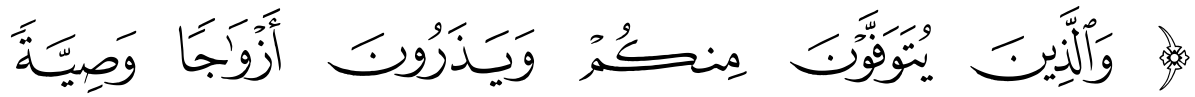

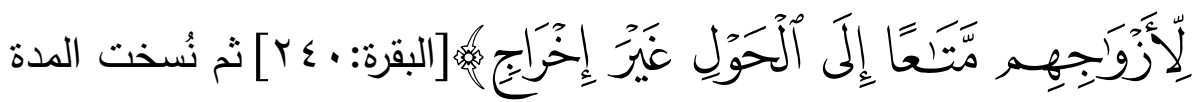
إلى أربعة أثهر وعشرة أيام، إلا أن تكون حاملً فبوضع الحمل، قال تعالى:

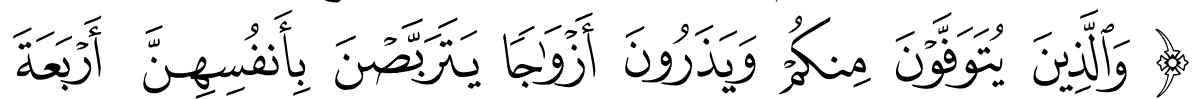

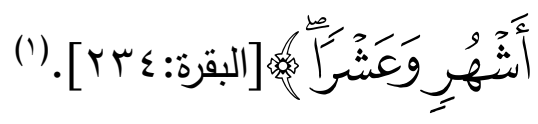

0- العدل بين النشاس.

إنَّ العدل من أعظم القيم التي أمر الله بها، وحثّ المسلمين عليها، قال تعالى : يأمرك يا محمد والمؤمنين في كتابه بالعدل، وللمفسرين في معنى العدل في الآية عِدَّة معانٍ، منها: الثهادة، وقيل: القضاء بالحق، وقيل: الإنصاف وترك الظلّلم، فالإسلام دين المثالية، فلا فضل فيه لعربي على أعجمي إلا بالتقوى، فلا بتفاضلون بجنسٍ، أو نسٍ، أو لون، وإنما بالإيمان والعمل الصالح. (r)

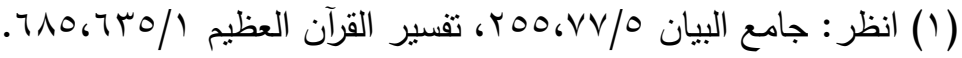

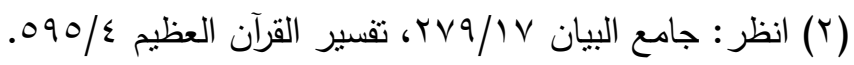


وقد دعت نصوص الثربعة إلى تطبيق العدل والمساواة، ونهت عن

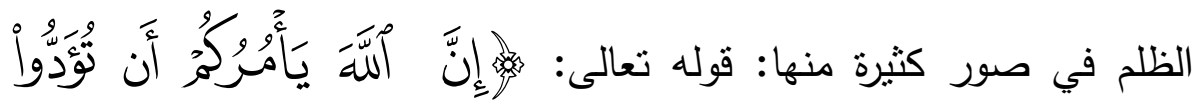

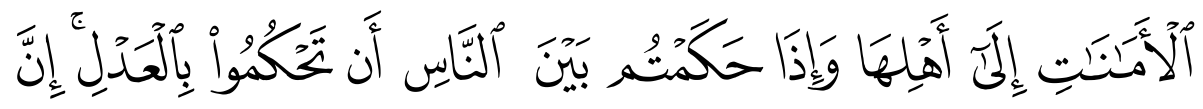

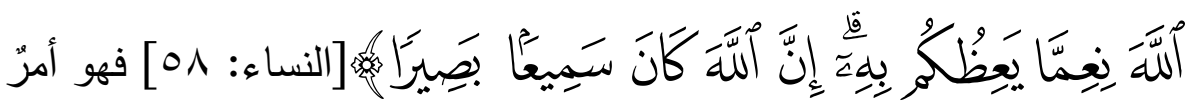
من الله تعالى بالحكم بالعدل بين الناس، فهي عامة لكلّ حاكم، وإن خصَّها

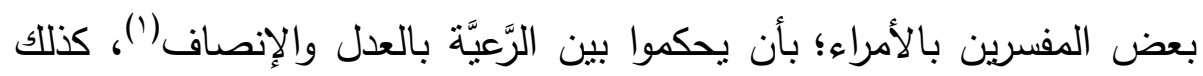

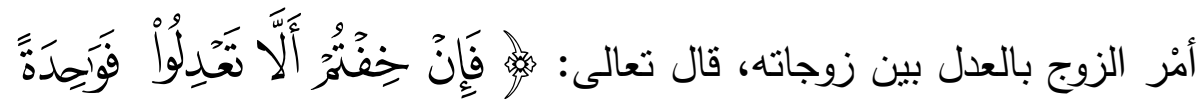

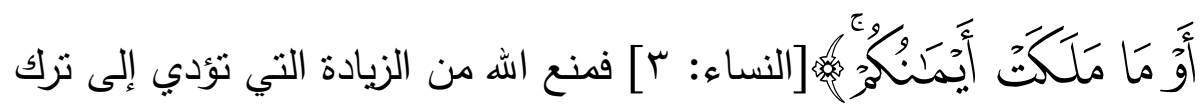
العدل بين الزوجات، والمعنى: إن لم يستطع الزوج العدل بين اثثتين إلى أربع زوجات في القَسْم وطيب المعُشر فواحدة، فإن خاف ألا يعدل في الواحدة فمَّما ملكت يمينه، وفي هذا دليل على أنَّه ليس هناك حقٌ لملك اليمين في القِسمة

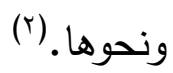

ومن صور العدل أيضًا: عدل الحاكم في معاملة الرعية، وعدل الأبوين بين الأبناء، والعدل في معاملة غير المسلمين، إلى غير ذلك من الصور التي جعلت العدالة في الإسلام مضرب الأمثال، فالكل في ظل العدل ينعم

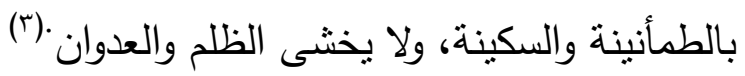

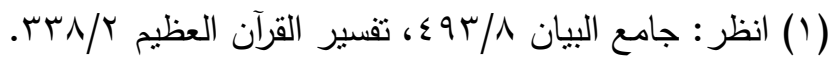

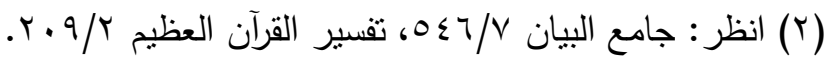

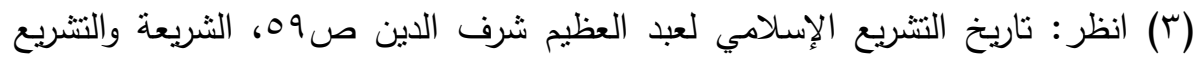

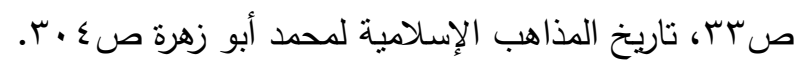


צ- - أنَّ التشريعات القرآنية طريق هداية إلى اله تعالى، قال تعالى:

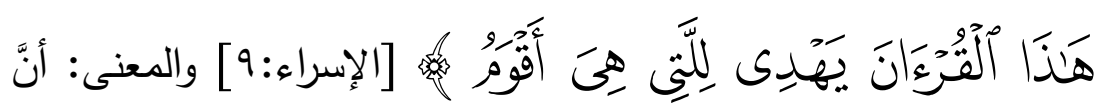

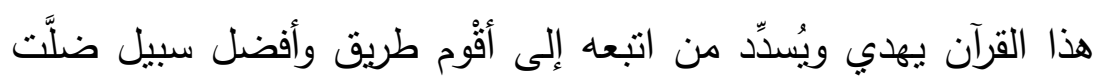

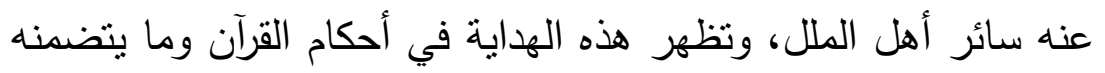

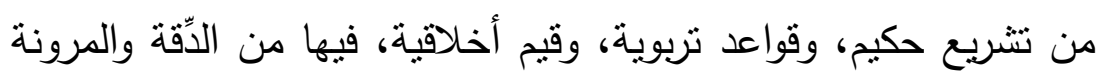

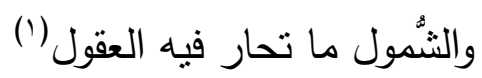

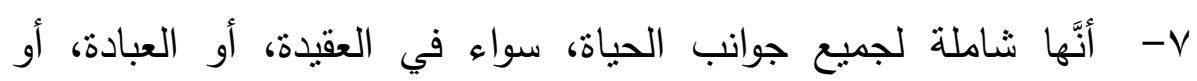
الاقتصاد، أو السياسة، أو الاجتماع، أو غيرها.

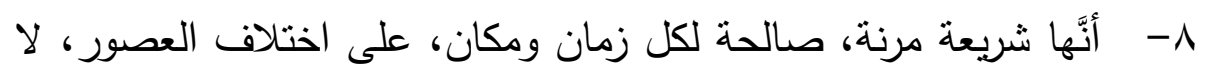
خلل فيها ولا قصور .

9- التشريعات القرآنية ثابتة لا تتبدل ولا تتغير ؛ لأنها تتزيل من حكيم حميد،

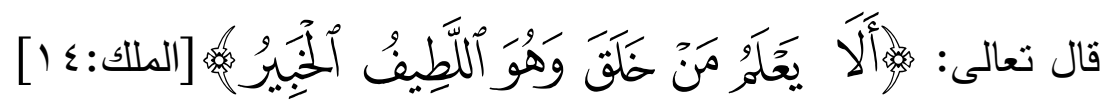

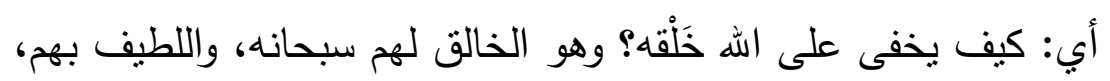

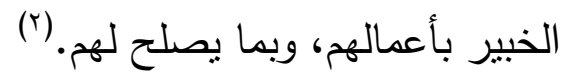
• 1 أنَّها رسالة عامة للعالمين، تحمل في مضمونها رحمة أرحم الراحمين،

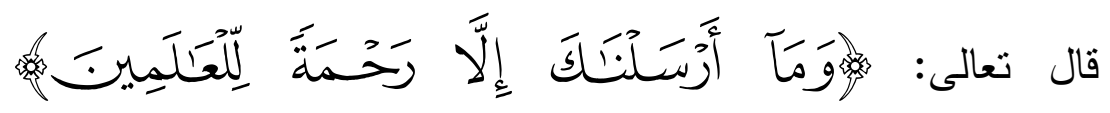
[الأنبياء:V·1] والمعنى- كما روي عن ابن عباس رضي اله عنهما

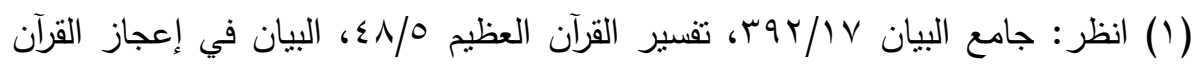

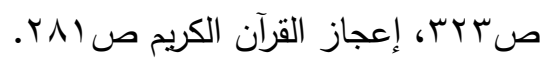

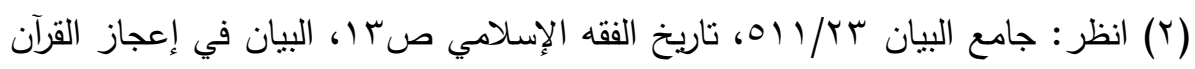

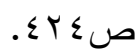


وغيره من المفسرين - : أنَّ اله أرسل نبيه

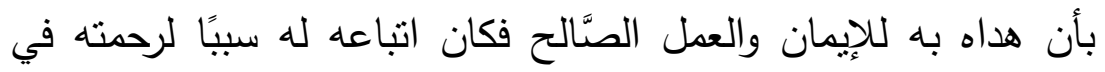

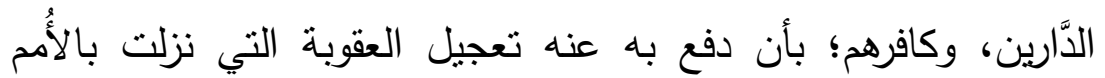

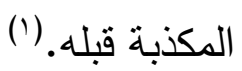
إلى غير ذللك من مزايا الثرع العظيم؛ التي جعلته معجزة أبهرت الجميع، الكئل لاسيما أصحاب الفكر السَّقيم.

\section{أقوال الغرب في التشريع الإسلاهي.}

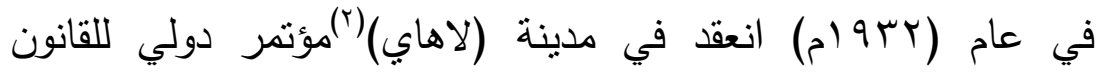
المقارن، وقد اعنرف أعضاؤه من رجال القانون الألمان، والإنجليز ، والفرنسيين:

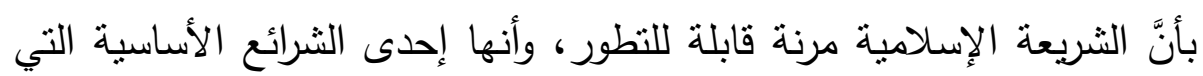

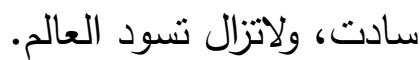

ولم يقف الأمر عند هذا الحد، فقي عام (ولامدام (م) عُقد هذا المؤتمر

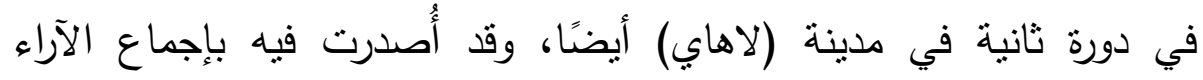

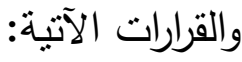

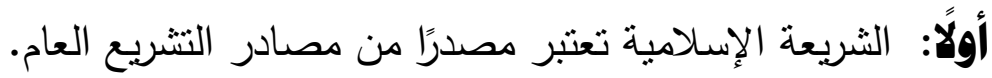
ثانياً: تعتبر الثريعة الإسلامية حية قابلة للنطور . ثالثًا:تعتبر الثريعة الإسلامية قائمة بذاتها، وليست مأخوذة عن غئلة غيرها.

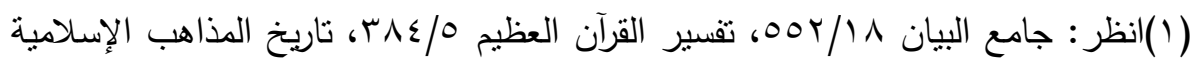

$$
\text { صع :r. }
$$

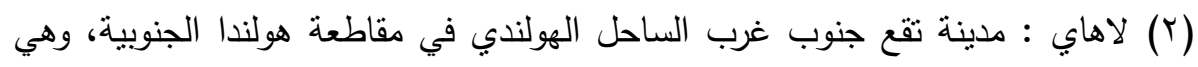

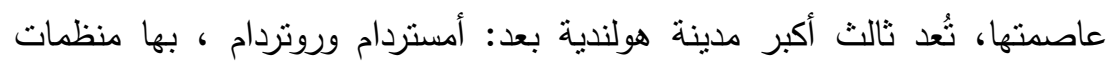

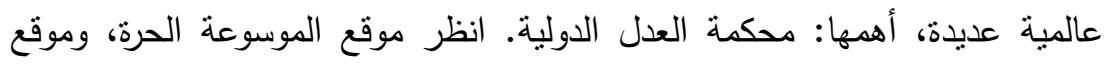

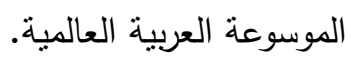


وفي عام (9^^ (م) شهدت المدينة نفسها مؤتمر المحامين الدولي، واشترك في هذا المؤتمر ثناث وخمسون دولة، وقد أصدر هذا المؤتمر القرار الآتي -بناء على اقتراح قدمته لجنة النتربع المقارن-: " اعترافًا بما في التشريع الإسلامي من مرونة، وما له من شأنٍ هام، يجب على جمعية المحامين الدولية أن تقوم بتبني الدراسة المقارنة لهذا التشريع، وبالنشجيع عليها".( (1)

* * * * * * * *

(1) انظر : تاريخ التشريع الإسلامي لعبد العظيم شرف الدين صـ وما بعدها. 


\section{المطلب الأول \\ الإعجاز التشريعي في الزكاة.}

إنَّ في تشريع الزكاة وجعلها الركن الثالث من أركان الإسلام أسرارًا

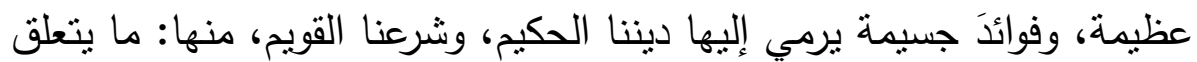

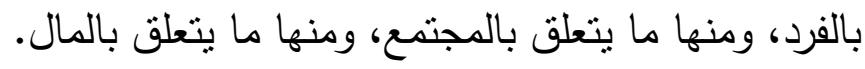

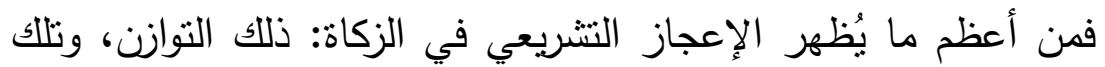
الوسطية؛ حتى لا يبغي غنيّ على فقير ، ولا يحقد فقيرٌ على غنيّ.

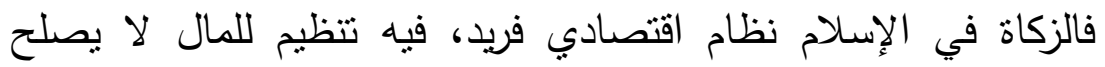

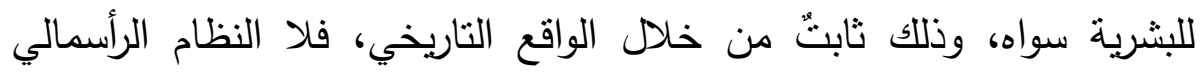

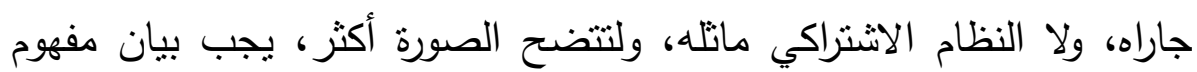

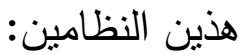

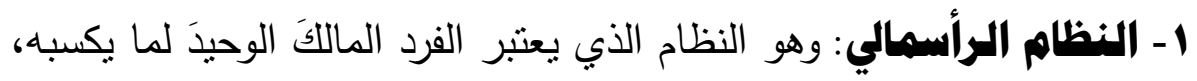

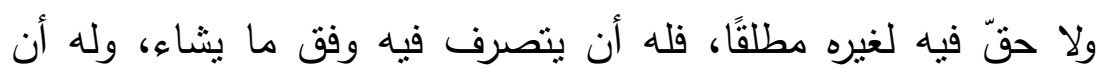
يصرفه في الوجوه التي تعود عليه بالمنفعة.

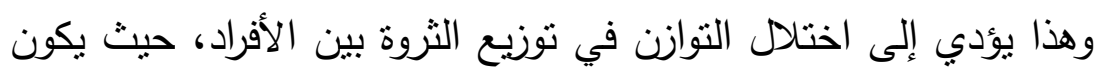

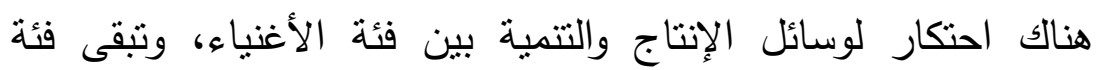

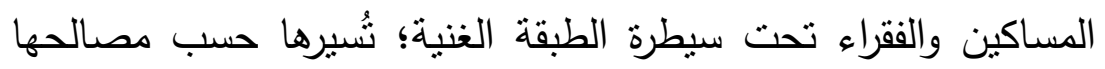
وما ينفعها. r- النظام الاشتراكي: وهو النظام الذي يوجب أن نكون وسائل الإنتاج

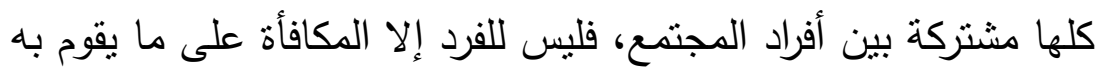

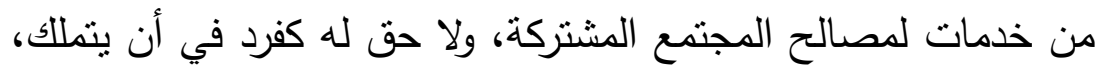
أو يتصرف فيها بحسب رغبته.

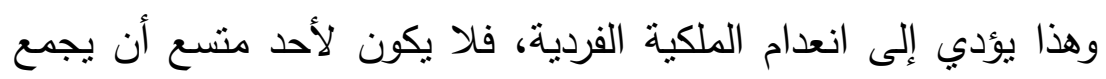
المال ويستثمر فيما يشاء من وجوه النماء وزيادة الإنتاج. 
أمَّا التشريع الإسلامي الخالد بمنهجه السَّليم القويم، فهو يتتاسب مع ولئح

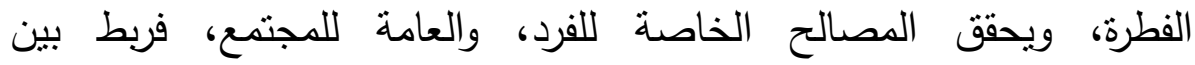

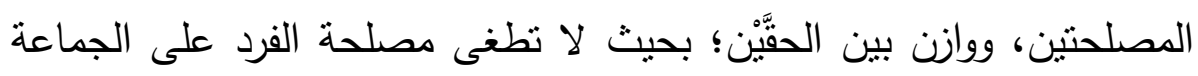

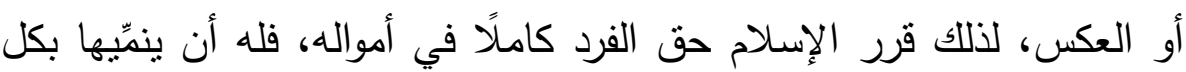

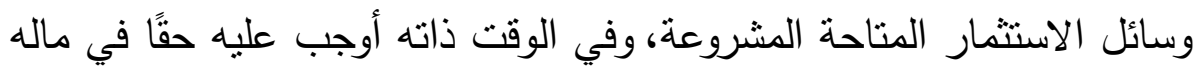

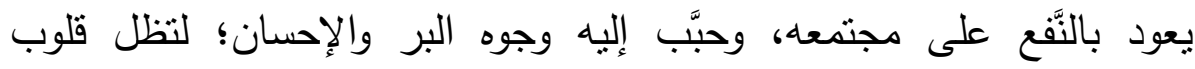

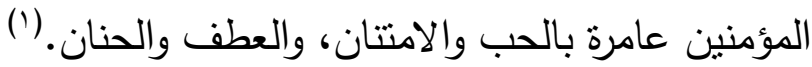

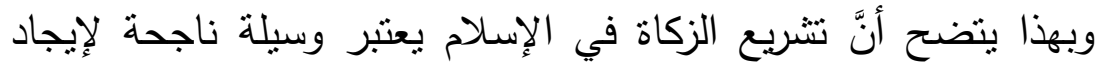
مجتمع متعاون متكامل، ويظهر ذلك جليًا في الحكمة من مشروعية الزكاة، الإنا

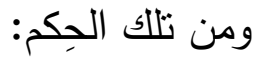
ب- أنَّ في أدائها طاعةً لله، واستجابةً لأمره.

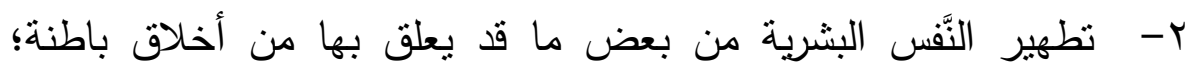

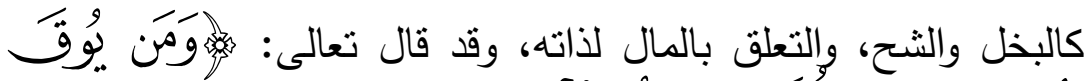

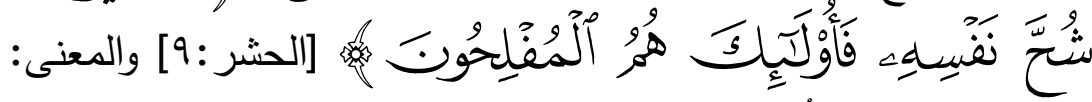

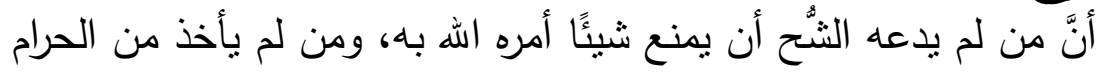

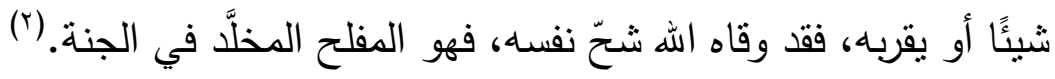

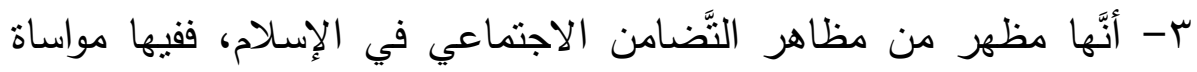

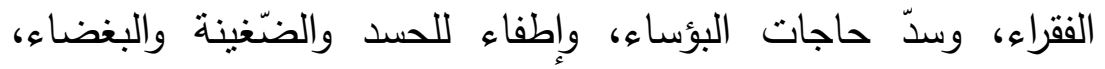

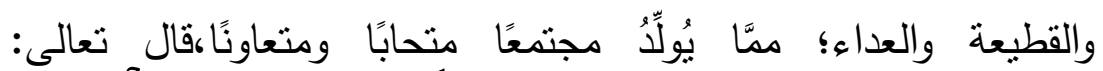

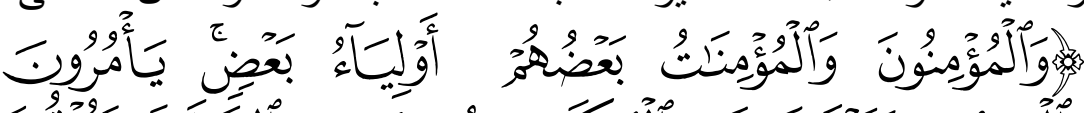

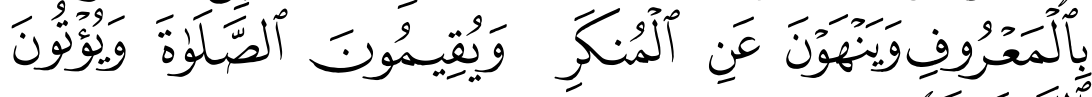

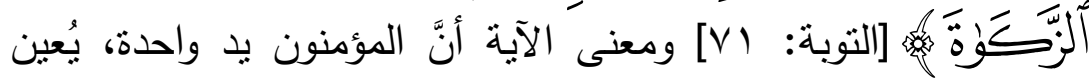

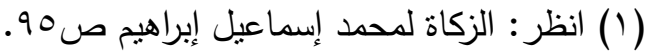

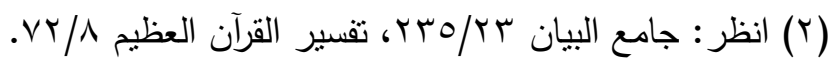


بعضهم بعضاً ويتتاصرون، ويتعاضدون، ويتتاصحون بالإيمان والخير،

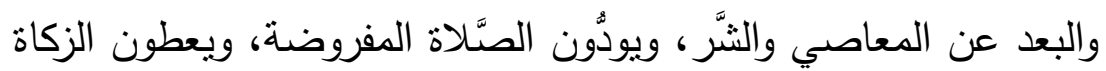

أهلها ومستحقيها استجابة لأمر الله. (')

ع- إقامة المصالح العامة للأُمَّة، حيث إنها تدعو إلى العمل، وتوجِّه إلى زيادة الإنتاجية، وذلك بتأمين وسائل العيش للمحتاجين؛ فيكون جميع أفراد

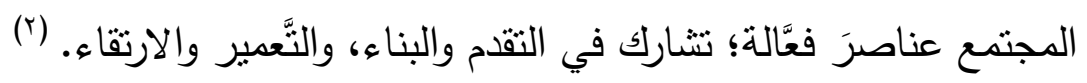

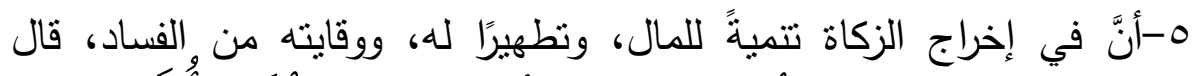

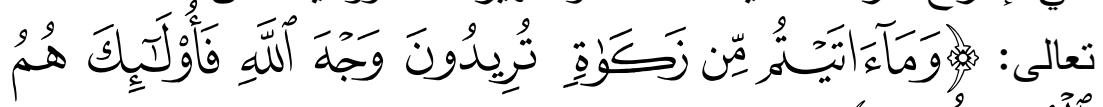

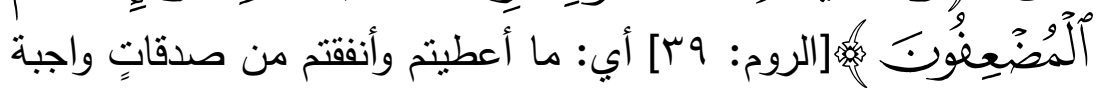
تبتغون بها وجه الله ومرضاته فيجازيكم عليها قيل: بالزبادة والخَلَف

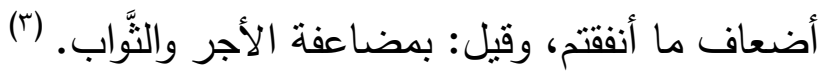

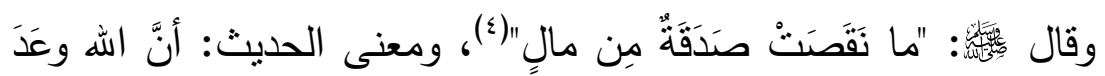

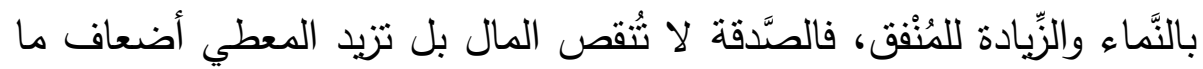

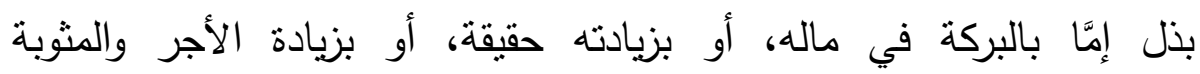
لأضعافٍ كثيرة. إلى غير ذلك من الحِكم الجليَّة.

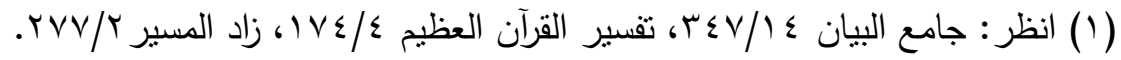

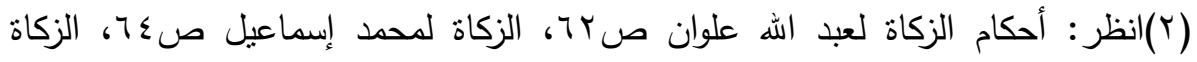

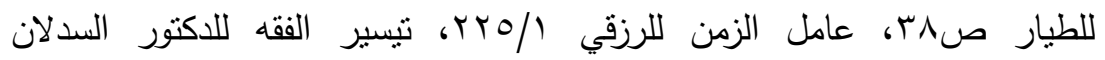
صמ rog

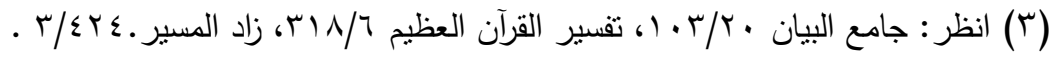

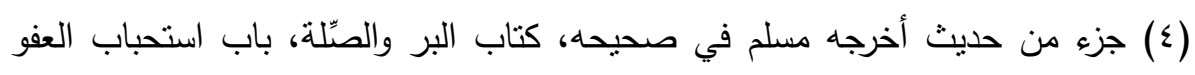

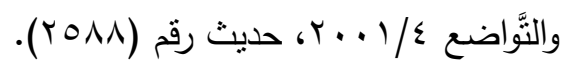




\section{الإطلب الثاني}

\section{أثر الزكاة على الغني " المُهطي"}

إنَّ الهه تعالى هو الذي وهب المال للإنسان، وأكرمه بأن جعله من الأغنياء، ولم يُكلِّفه في النَّقة ما لا يُطيق، ولم يُرهقه بإخراج المزبد من ماله؛

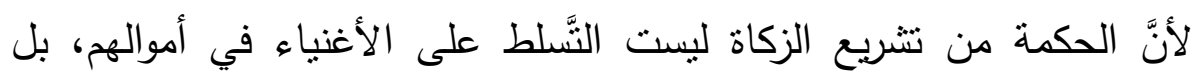

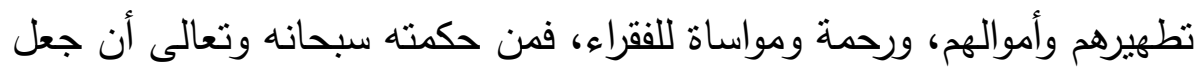
للزكاة أنصبةً محدَّدة بنسٍٍ معينة، ما بدل على ما في حكمة تشريع الزكاة من

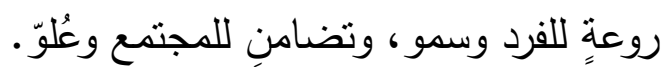

قال تعالى:

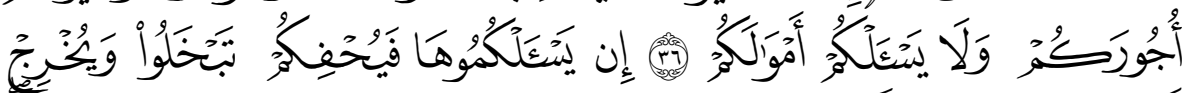

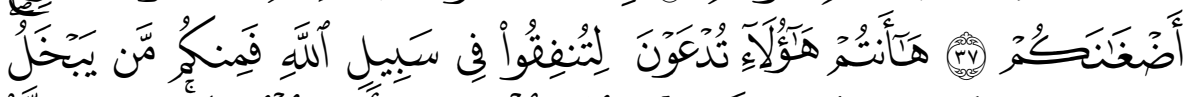

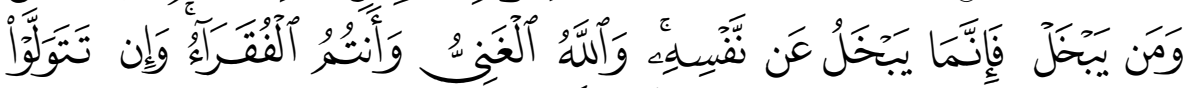

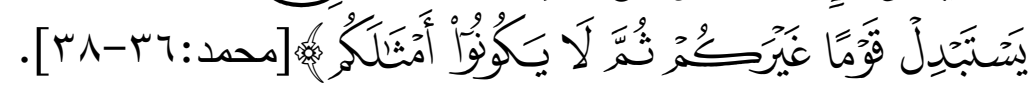

فبيَّن الله سبحانه في الآيات الكريمة أنَّ من رحمته أن لا يسأل الناس كثيرًا من أموالهج، وبيَّن الحكمة من ذللك بأنَّه لو أجهدهم بالسؤال، وطلبهر الكثير من أموالهم، لشقَّ ذلك عليهج، وبخلوا وامتتعوا، ولو فعلوا ذلك لكان أمرهم

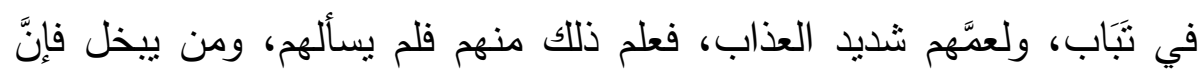
ذلك نابع من بخل نفسه، والإمساك طبعه، لكنَّ الجواد تأبى نفسه الكريمة إلا النَّقة في سبيل الله، وفي سائر وجوه الخير، والله الغني فلا حاجة له سبحانه إلى أموالكم ونفقاتكم، إنَّما أنتم الفقراء إليه بحاجنكم إلى أجر وثثاب الإنفاق. (')

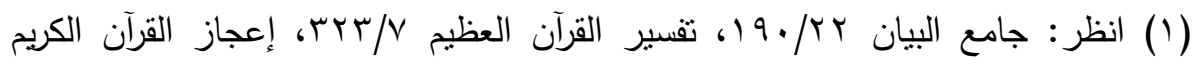

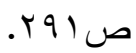


فمن الإعجاز التشريعي في فرض الزكاة وأثره على الغنيّ: 1- أنَّ في إخراج الزكاة تتمبةً للروح المعنوية للغني؛ وذلك بانشراح صدره، وسعادة قلبه، وسمو روحه؛ لأنَّه عند ما يُسدي الخير للغير، ويصنع المعروف، ويساعد الملهوف، ويوسع على الفقراء، تتعكس آثار العطاء

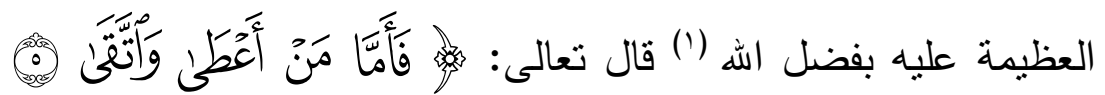

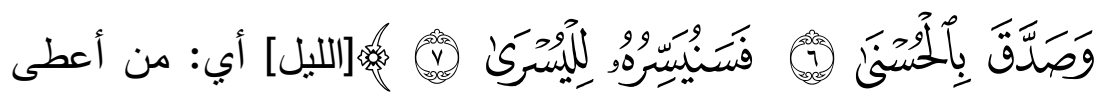
ما أمر الله بإخراجه لمستحقيه، واتَّاه، وصدَّق بلا إله إلا الله، وقيل: معنى الحُسنى في الآية الصّلاة والزكاة، وقيل: زكاة الفطر، وقيل: بالخَلَف من الله فيما أنفق، فسنيسره للخير، والحياة السَّعيدة الحسنة

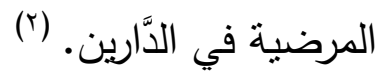
r- - أنَّ في إخراج الزكاة تطهيرًا لنفس الغني من بعض ما قد يعتريها من شَّ

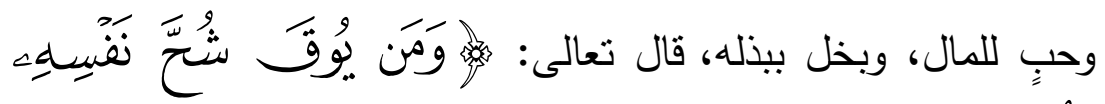

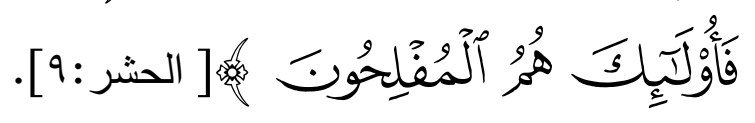

وهذا ما تعجز عنه القوانين الوضعية وغيرها؛ لأنَّ النَّفس مجبولةٌّ على حبِّ المال، فهذا من أعظم صور الإعجاز في تشريع الزكاة؛ حيث يُدفع المال

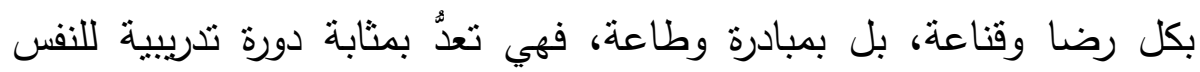

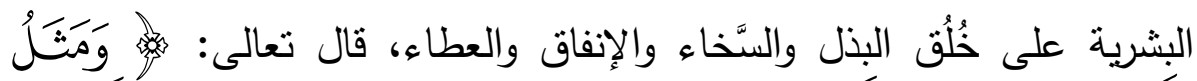

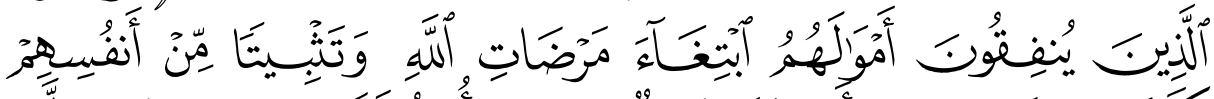

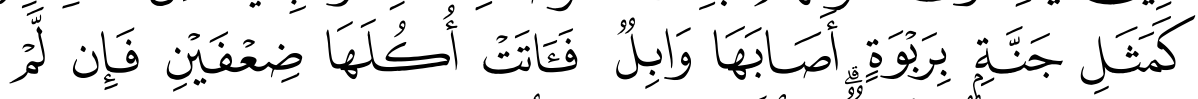

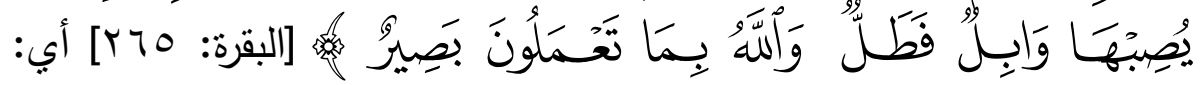

(1) (1انظر : الزكاة للطيار صبمان.

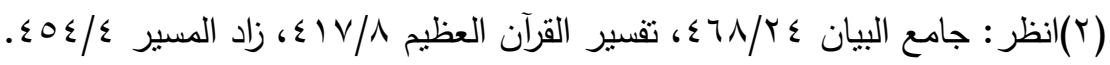


مَتَّل الَّذَين يتصدقون بأموالهم في وجوه الطَّاعات المختلفة من تقوِية المجاهدين في سبيل الله وإغاثة الملهوف وإعانة الضَّعيف؛ وذلك يقيناً منهم، وتصديقاً بوعد الله بمجازاتهم في الدَّارين كما رجَّحه جماعة من المفسِّرين كقتادة وابن جرير وغيرهما، ورُوي عن مجاهد والحسن أنَّ معنى التثبيت في الآية أي:

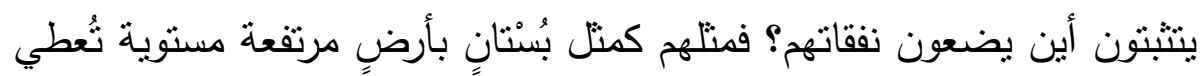

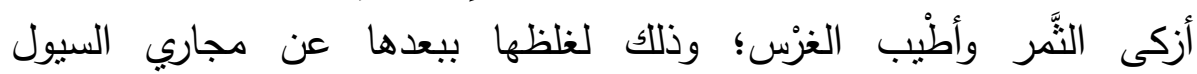

والأودية. (') (1)

r- أنَّ في إخراج الزكاة تطهيرًا للعبد من الذنوب والمعاصي، قال تعالى: فئل

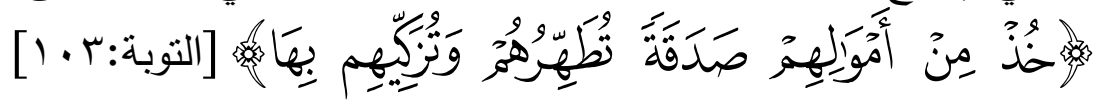

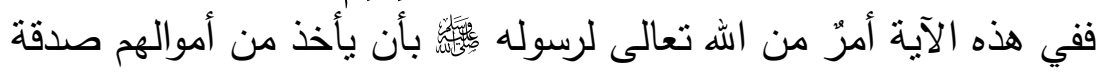

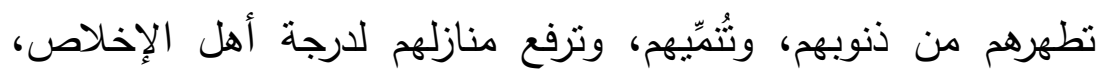

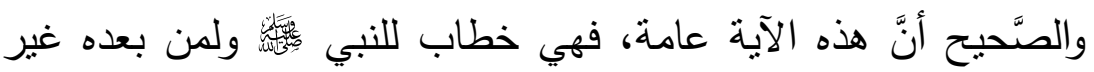

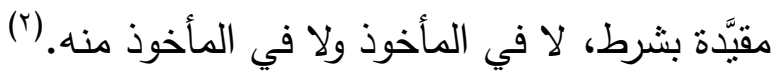
ع- أنَّ الزكاة بدفعها لمن يستحقها تجعل المؤمن يستشعر فضل اله عله عليه، ومنته وإحسانه؛ بأن أكرمه بالمال، وجاد عليه بالخير ، وجعل يده العليا،

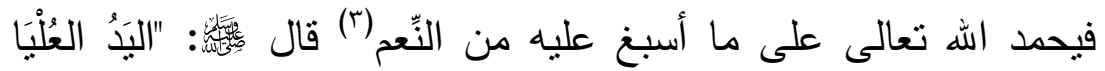

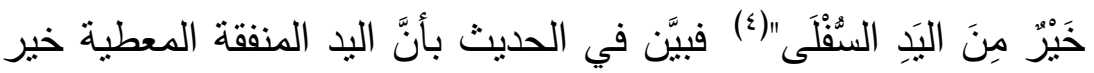
وأحب إلى الله من اليد الآخذة للصَّدقة.

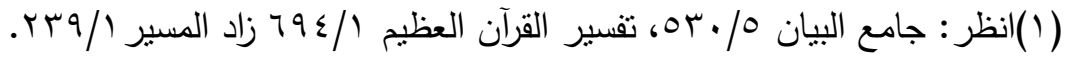

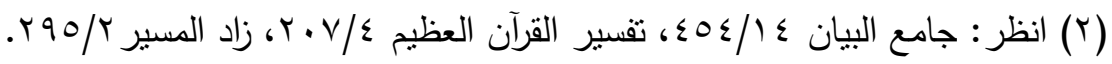

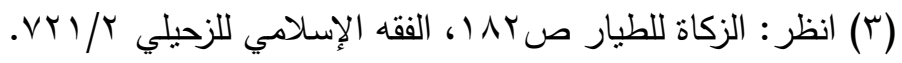

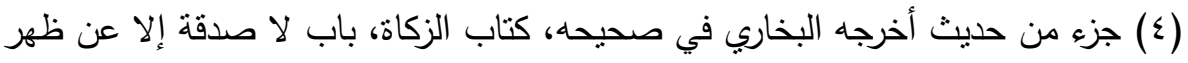

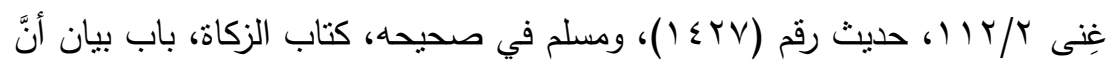

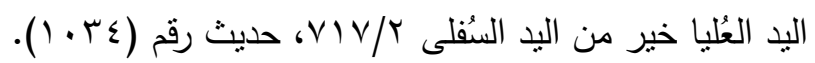


0- أنَّ من أعظم صور الإعجاز عند إخراج الزكاة: أنَّ الظاهر نقصان

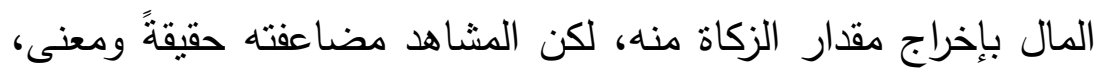

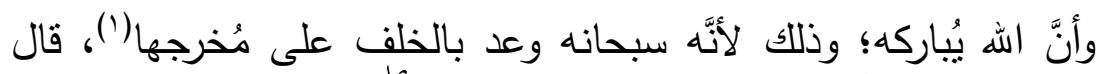

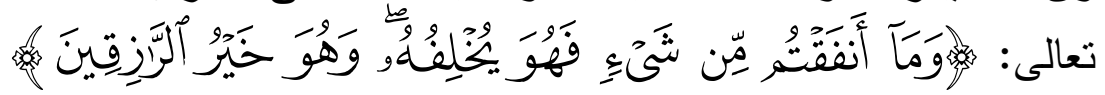

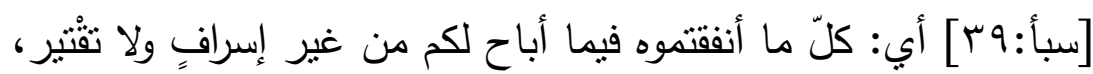

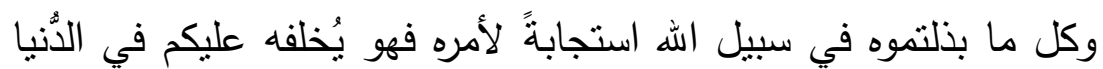

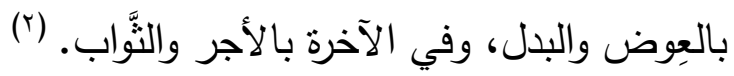

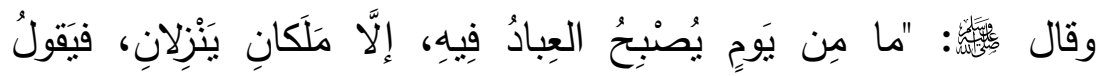

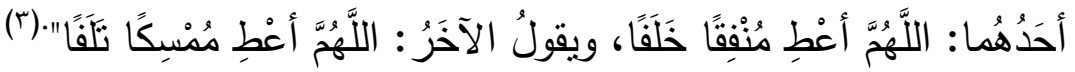

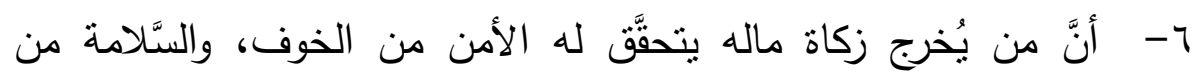

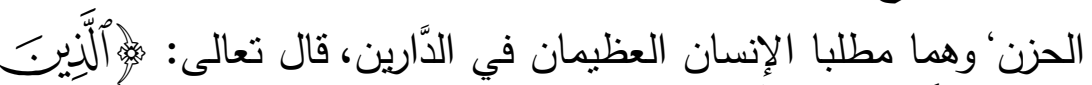

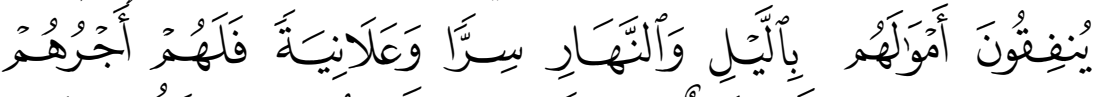

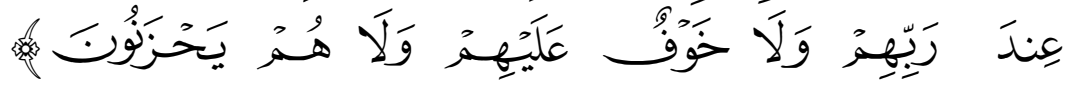

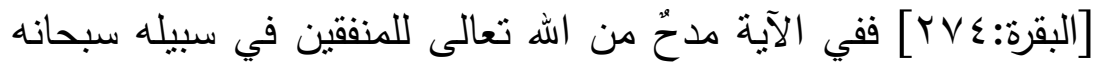

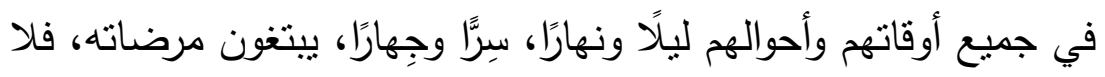

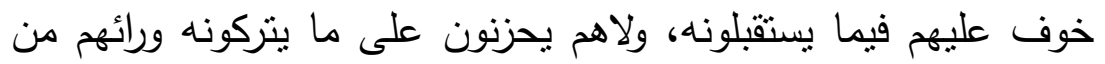

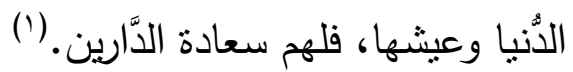

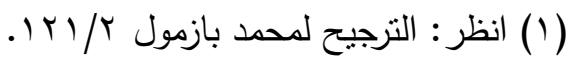

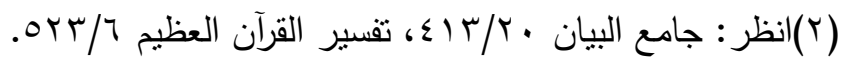

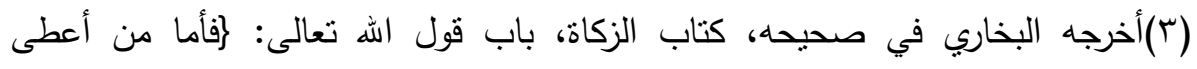

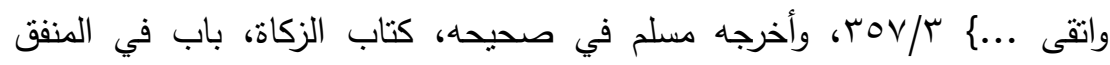

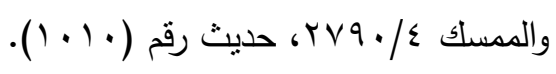

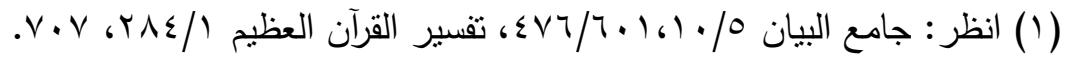




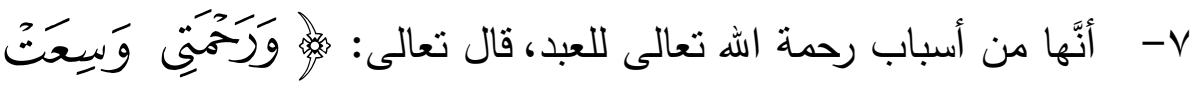

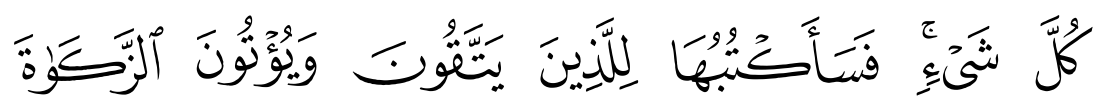

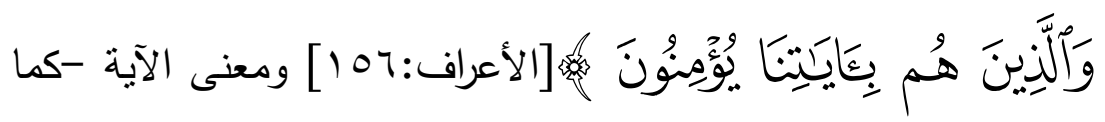

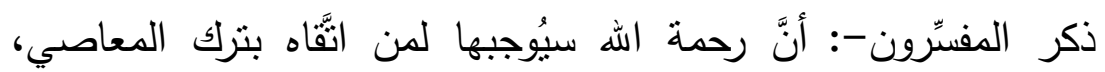

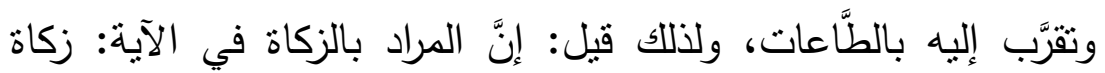

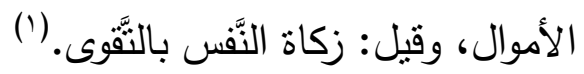

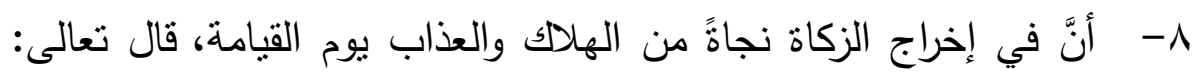

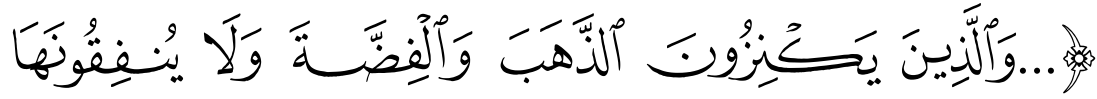

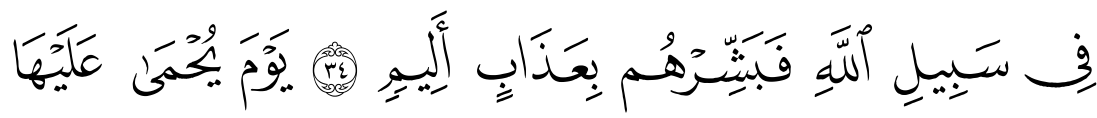

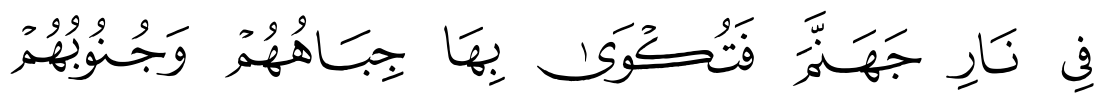

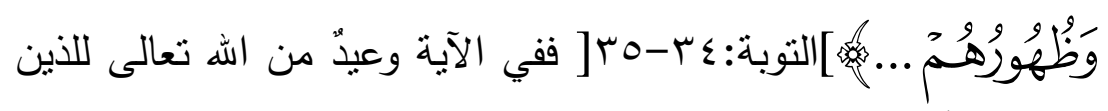

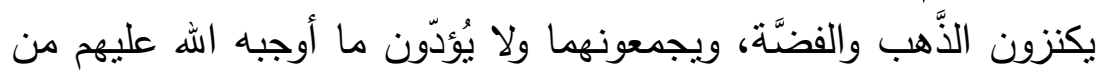

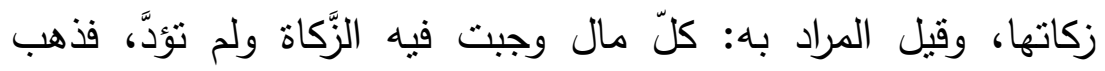

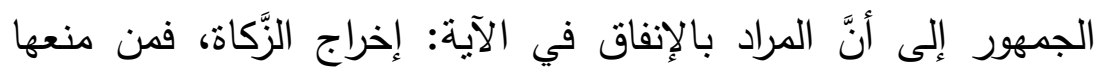

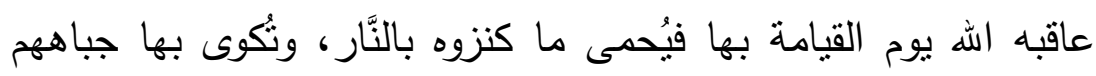

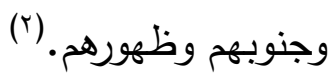

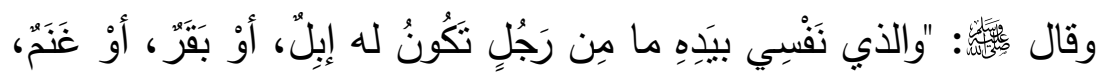

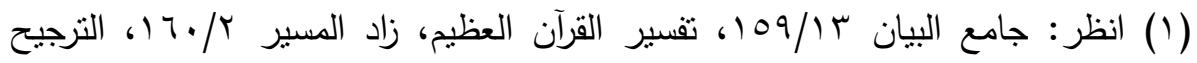

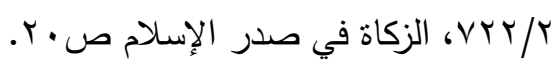

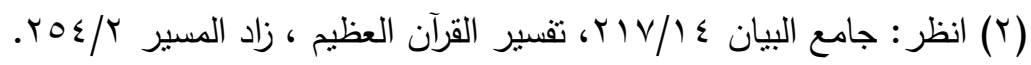

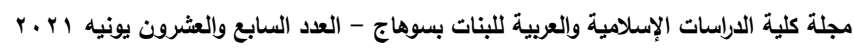




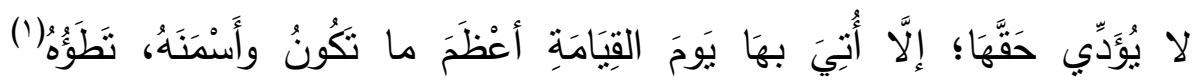

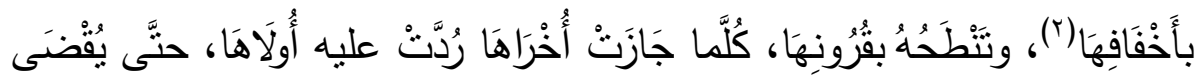

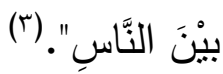

فالمؤمن يستشعر بإخراجه للزكاة إيمانه باليوم الآخر، ومسألة الأجر والثواب، والوِزر والعقاب إن منعها أو قصر فيها، فلا بتحايل في إخراجها، بل بل بله يوقن بأنَّ الله بعمله بصير ، وسيُحاسبه على الصغير والكبير، فتكون نفسه عليه رقيبة، لوامةً وحسيبة.

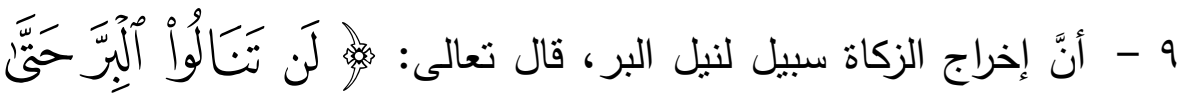

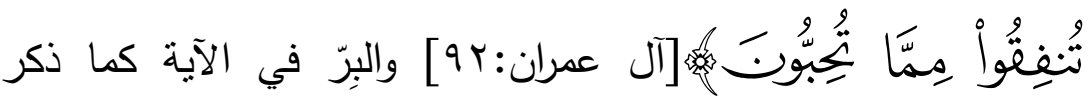
المفسرون-: المراد به الجنَّة كما رُوي عن ابن عباس رضي الله عنهما، ومجاهد، وقيل: الطَّاعة، وقيل: الخير الذي يُنال به الأجر، وقيل: التَّقوى، والمعنى لن تدركوا البرّ الذي ترجونه بطاعتكم لله وتطلبونه بعبادتكم إيَّاه؛ وذللك بتقضله عليكم بالفوز بالجنة والنَّجاة من النَّار ، حتى بـى

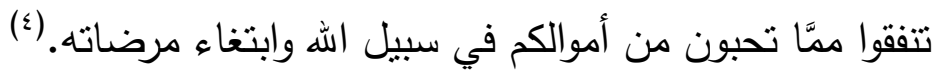
• أ-أنَّ في إخراجها تحقيقًا للعبودية، والتقرُب للربّ بإخراج محبوب العبد له،

(1) الوطء في الأصل : الدوس بالقدم ، فسمي به الغزو والقتل ؛ لأن من بطأ على الثيء

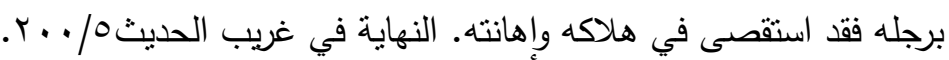

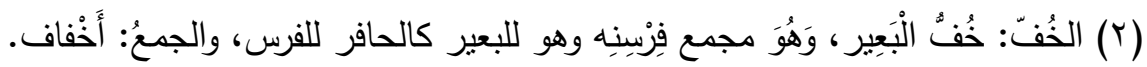

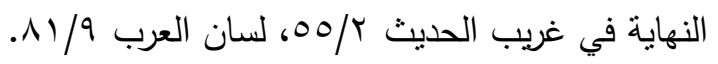

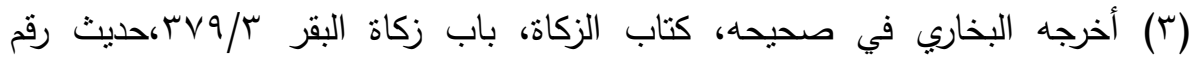

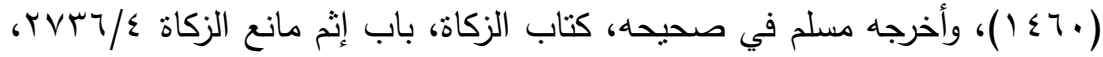

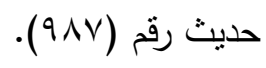

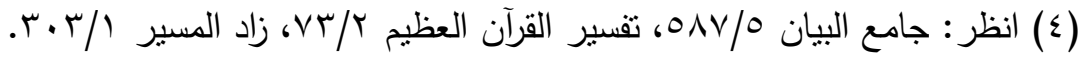




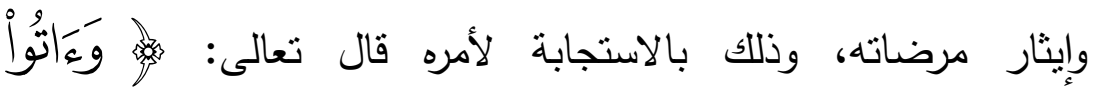

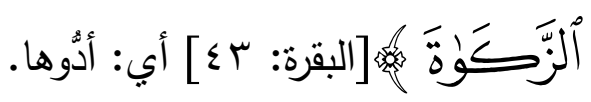

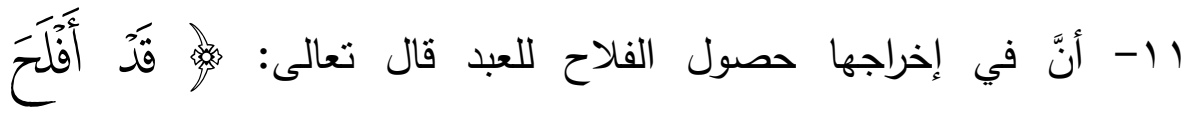

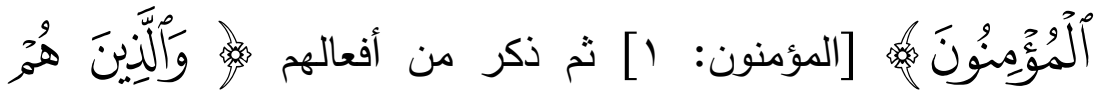

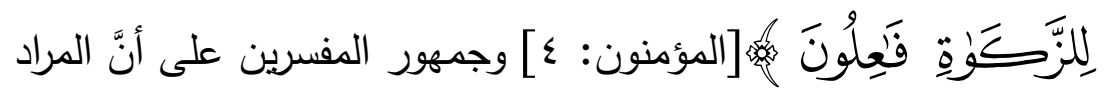
بالزكاة في الآية زكاة الأموال، فهي بشارة من الله لمن يؤدي الزكاة

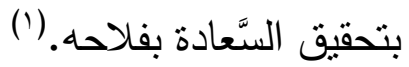

rأ- أنَّ من الإعجاز التشريعي في إخراج زكاة الفطر و وثمراته على الغني:

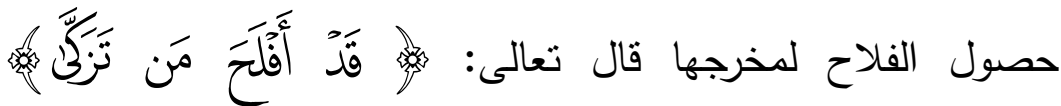

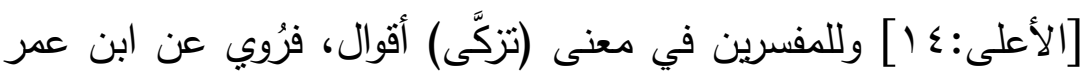

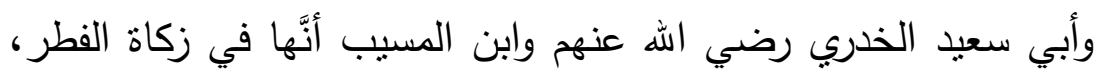

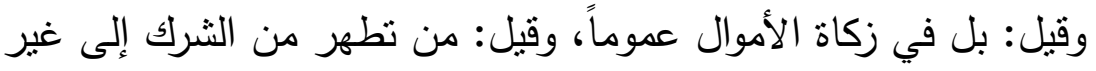

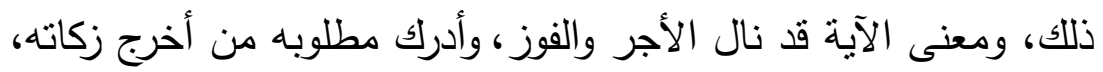

$$
\text { وطهُّر أعماله. }
$$

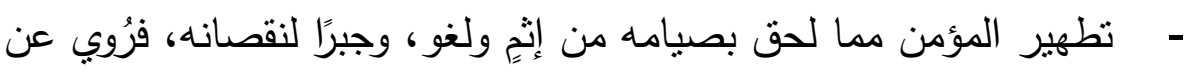

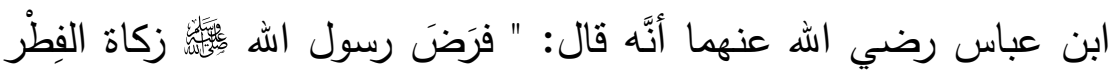

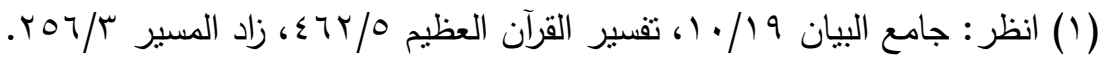

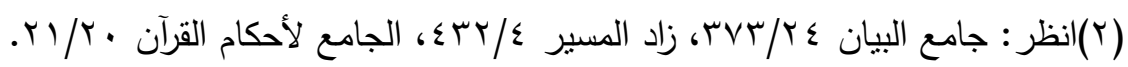

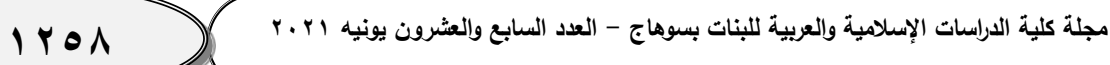




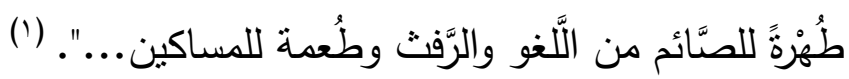

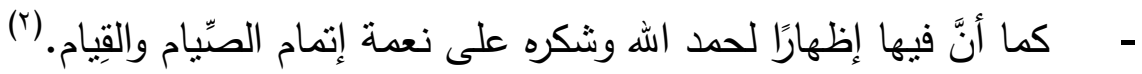

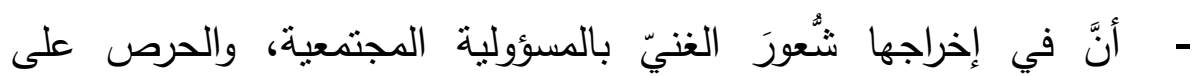
مشاركة الفرح والخير مع الغير • - أنَّ في إخراجها نشرًا للألفة والمحبة والسَّلام بين أفراد المجتمع، وقمعًا للحسد والضَّغنينة والطمع.

* * * * * * * *

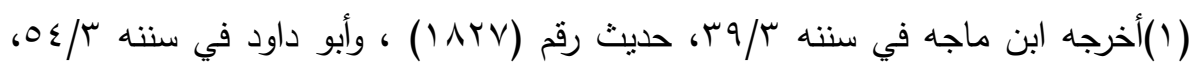

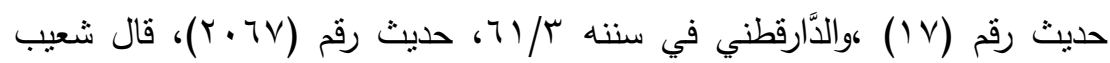

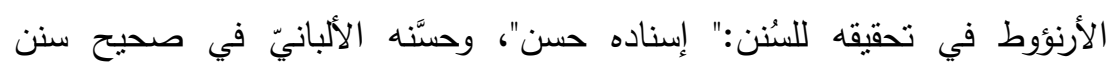

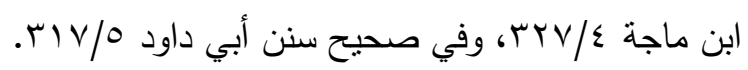

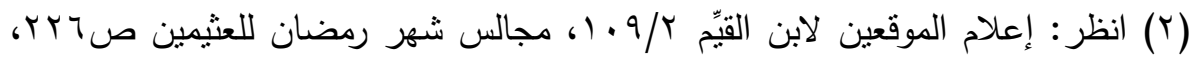

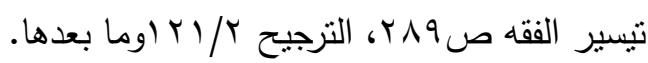




\section{الإhلب الثالث}

\section{أثر الركاة على الفقير "الأتُلَِّي"}

لقد اهنمّ الإسلام بالققراء ومواساتهم، وأولاهم العناية العظيمة، وذلك حين

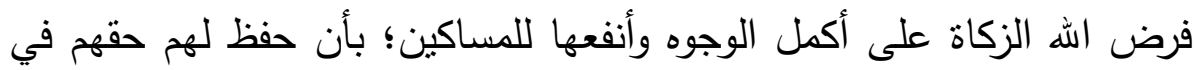
الكرامة، وساق إليهم رزقهم بأمنٍ وسلامة، وجعل الإحسان إليهح للإيمان علامة، فما يُعطونه من أموالٍ وصدقات وإحسانٍ وزكوات، إنَّما هي حقُ لله تعالى، يُعطاه المحتاج والفقير ، وهو عزيز النَّفس مرفوع الرأس، فيتحقَّق له بذلك وهي الاستقرار المالي والنَّفس، وكذلك راعى في المستحقين لها أمرين مهين،

$$
\text { وهما: حاجة الآخذ، ونَفْعه، وحرَّمها على من عداهما. }
$$

وهذا كله بدلّ على إعجاز هذا التشربع وحكمته، ووسطيَّته وتوازنه، فحفظ وحني حق الغنيّ والفقير على السَّواء، فلا ضرر ولا ضِرار، بل دعوة للتعاون وحفظ

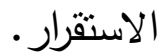

فمن صور الإعجاز التشربعي في فرض الزكاة من حيث أثرها على الفقير : (1)

1- أنَّ الزكاة تطهر نفس المحتاج والفقير من داء البُغْض والحسد، والضَّغنينة والحقد، فالققير حينما يرى الأغنياء يتتعَّمون بخيراتهم، ويتفاخرون بثرواتهم، ويتلذَّذون بطيب عيشهم، ولا يحُسنون إلبه أو يعينونه، حينها لئرياء

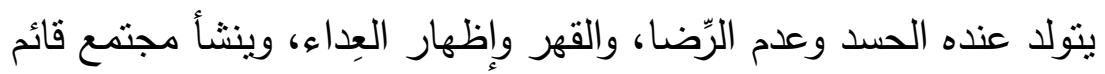

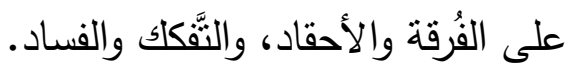

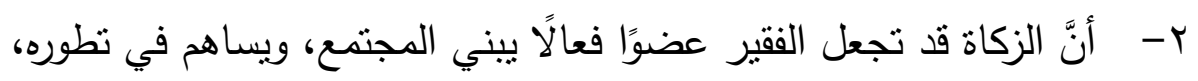
فقد يمتلك المحتاج الكثير من القدرات والإمكانات، لكن ينقصه المال والدَّعم، فبمجرد الإحسان إليه يُنتج ويعمل ويُسهِه، وبذلك يحقِّق عائدًا 


\section{كبيرًا، وتقدَّمًا للمجتمع المسلم. (')}

وقد ذكر بعض الفقهاء أنَّه لابد أن بُعطى الفقير والمسكين كفايته، وما يُخرجه من الحاجة إلى الغنى، وما يُعينه في حرفته، ويختلف ذلك

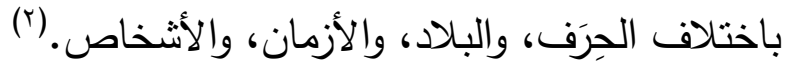

ب- - أنَّ الإسلام راعى النَّاحية النفسية للفقير، فالنفس البشربة بطبيعتها -في الغالب-لا تحبّ أن نكون في موضع الضَّعف والحاجة، وطلب العون من الغير؛ لذلك حفظ الله للفقير أمانه النَّنسي، واستقراره المالي، فحرَّم الإسلام اتباع الصَّدقة بالمنِّ والأذى، بل جعل ذلك مما يبطل الصدقات عمومًا، فما باللك بالزكاة المفروضةٌ؟. قال تعالى :

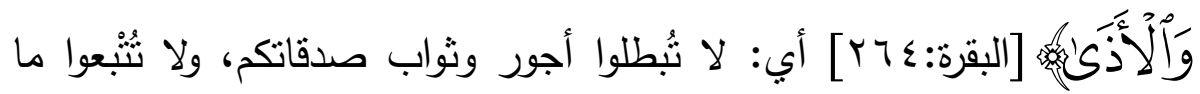
أنفقتم منها ومن الزَّكوات والخيرات بالمنّ على من أعطيتوه وأحسنتم إليه، لا بقولٍ ولا بفعل، ولا تُلحقوه بمكروهٍ أو أذى، كما بَطَلَ عمل المنافق الذي يُنفق ماله رياءً وسمعة لأجل حَمْد النَّاس له ووصفه بالكرم، وهو يُبطن التَّكذيب بالله

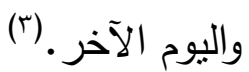
والمتتبع لنصوص القرآن والسنة: يجد أنّ الصَّدقة والإنفاق قد ثُذكر في القرآن والسُّنة ويراد بهما الزكاة، وهو ما عليه جمهور العلماء(؛) قال تعالى:

$$
\begin{aligned}
& \text { (1) انظر : الزكاة للطيار صعـ اوما بعدها، إعجاز القرآن ص90؟ ب. }
\end{aligned}
$$

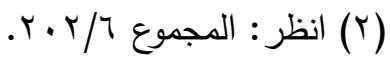

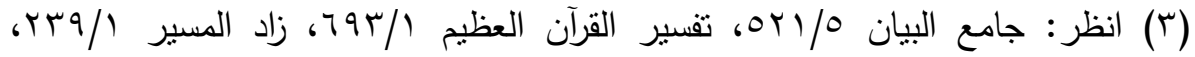

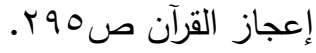

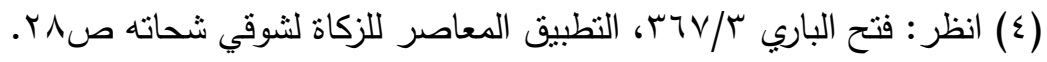




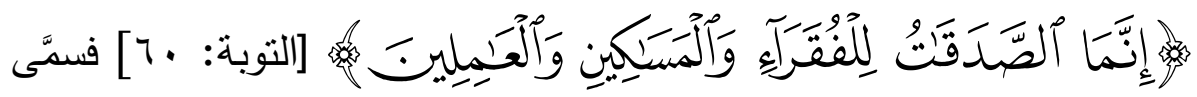
الله في هذه الآية الزَّكاة بالصَّدقة؛ لأنَّها ندلّ على صدق إيمان المؤمن بإخراجه

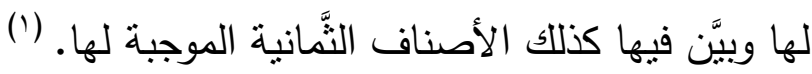

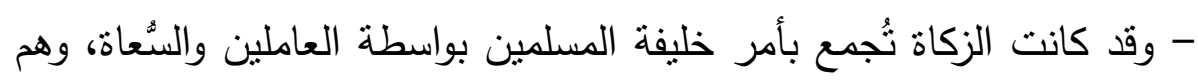

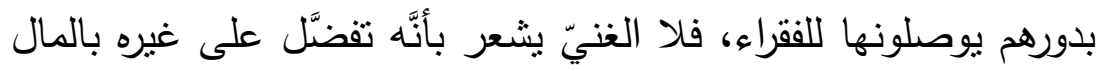

$$
\text { والعطاء، ولا الفقير يشعر بالحرج في أخذها. }
$$

ومازال الأمر كنللك في مملكتتا المباركة -إلا في النَّادر -حيث لا لا يتبين

أحيانًا من هم أهل الزكاة؟ فتُصرف في غير فير أهلها.

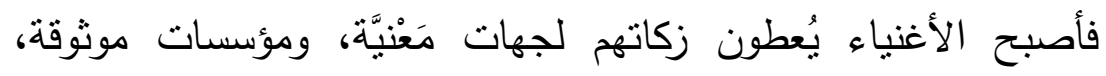

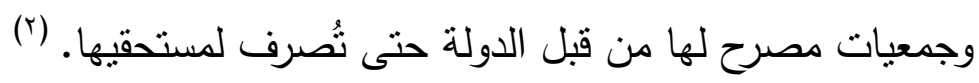

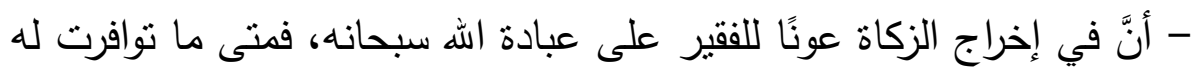

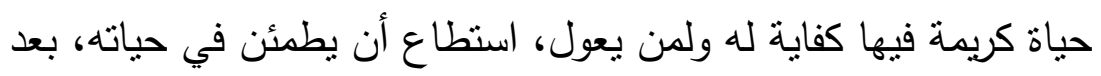

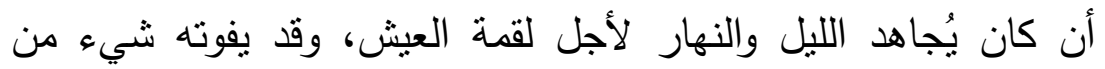

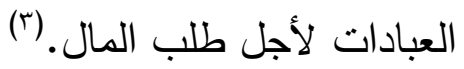

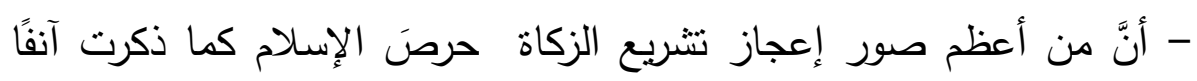

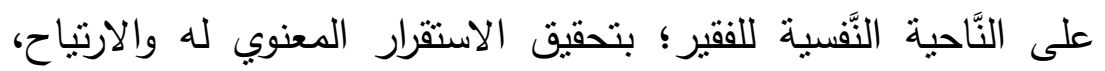

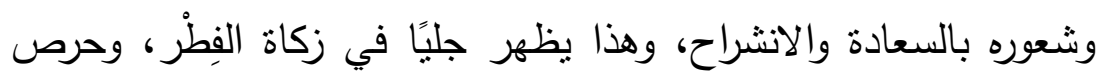
الإسلام على أن تكون جميع النفوس مبتهجة في يوم العيد.

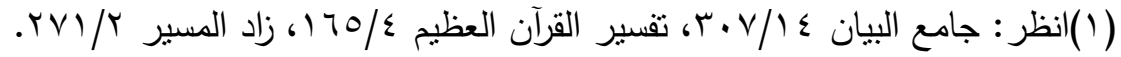

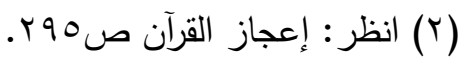

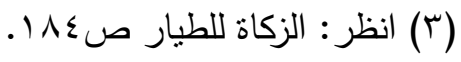




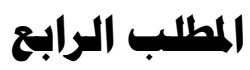

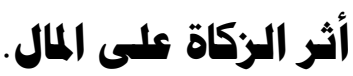

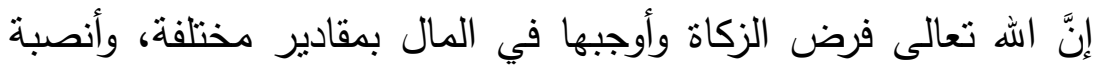

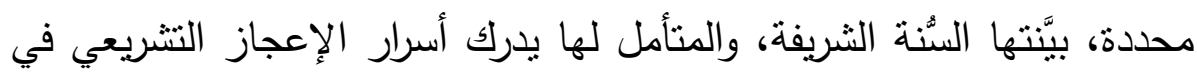

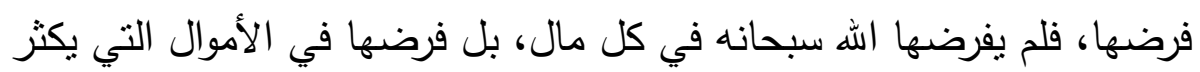



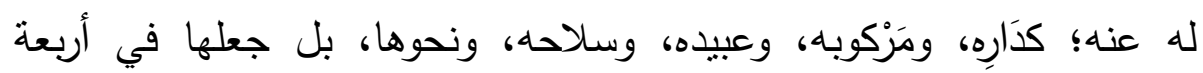

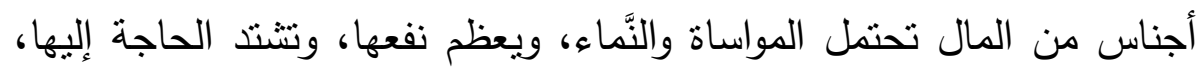

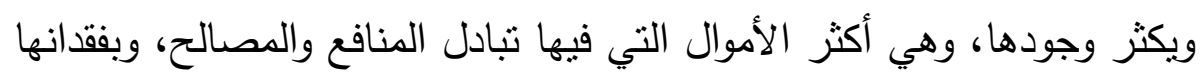

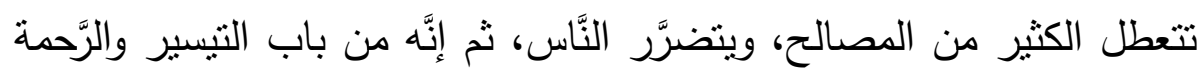

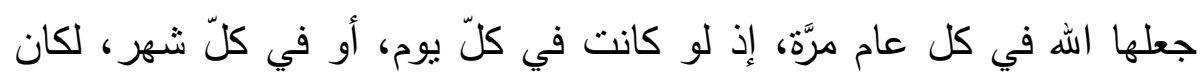

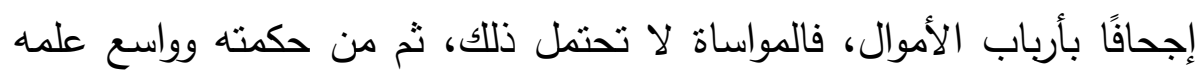

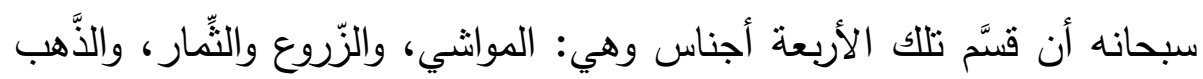

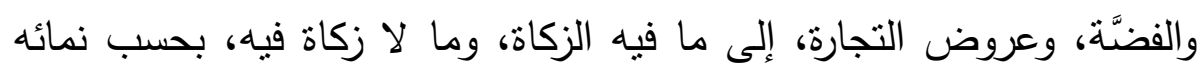

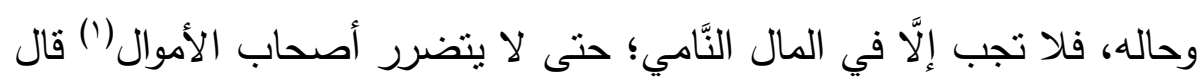

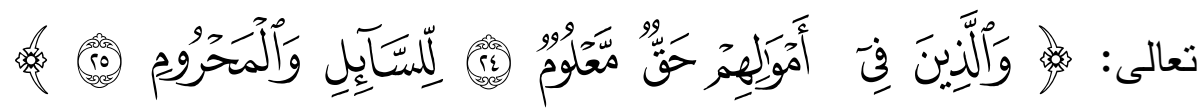

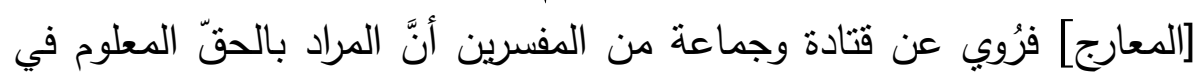

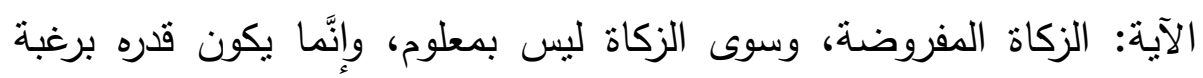

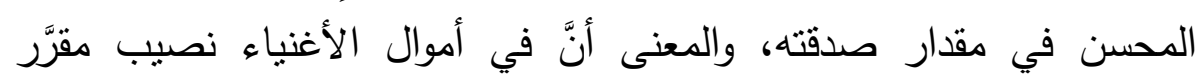

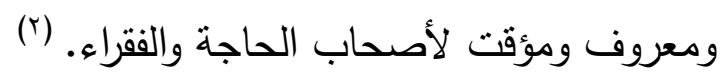

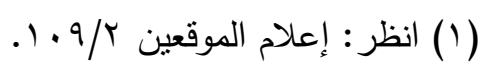

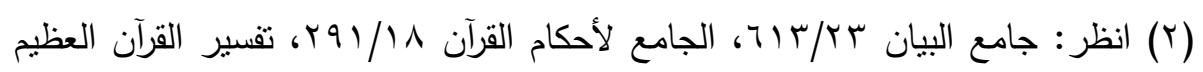

$$
\text { .rTV/A }
$$


فقسَّم المواشي إلى قسمين:

ا - ما فيه زكاة؛ ويكون في السَّائمة التي ترعى بغير كلفة ولا مشقة، فكلفتها

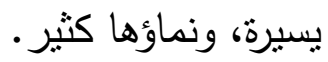

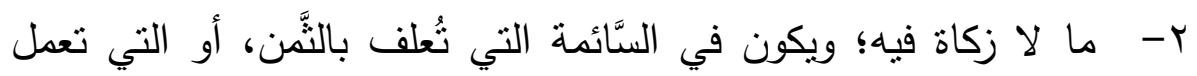

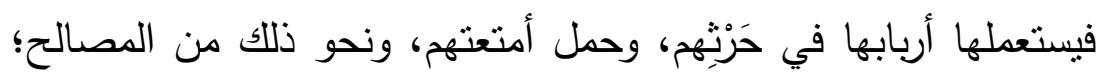
وذللك لكلفة المعلوفة. ثم قسَّم الزروع والثِّمار إلى قسمين: 1- قسم أوجب فيه العُشر إذ لا كلفة في نمائه ولا مشقة، فسنقيْه من ماء السماء. r- وقسم أوجب فيه نصف العُشر؛ فهو يُسقى بكلفة ومشقة، ولكن كلفته


زكاته بالكلية. ثم قسنَّم الذَّهب والفضيَّة إلى قسمين: بالَّا ا - قسم أوجب فيه الزكاة؛ وهو ما أُعدّ للتجارة، والتكسُّب، كالنَّقدين، والسبائك، ونحوها. ץ- وقسم لا زكاة فيه؛ وهو ما أُعدّ للاستعمال والانتفاع؛ كحليّ المرأة- على ونى قول الجماهير من أهل العلم-، وآلات السِّلاح التي يجوز استعمال مثلها، ولم تكن للتجارة. ثم قسَّم العُرُوض إلى قسمين: 1- ق قسم فيه زكاة؛ وهو ما أُعدّ للتجارة والنَّماء.

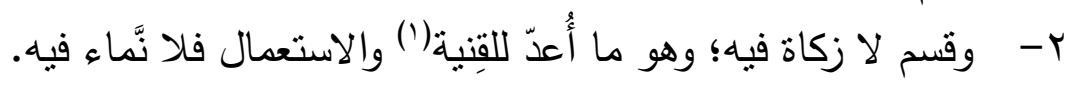
فهنالك فرقٌ في مقدار الزكاة بين ما فيه مشقة في تحصيله، وما لا مشقة وهاء فيه؛ من حيث النّّبة، وهذا من تدبير العليم الخبير ، وحِكمته سبحانه، فكلما

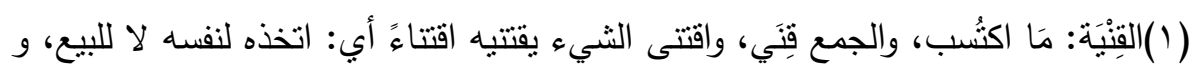

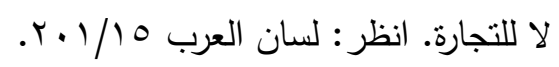


زادت المشقة والكلفة نقصت النّّبة، وكلما قلَّت الكلفة وكان الرّبّح أيسر زادت

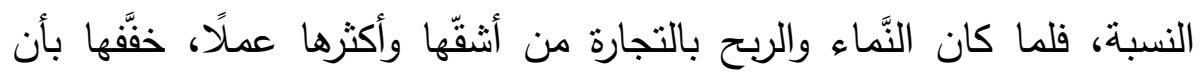

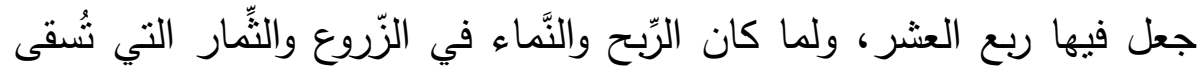

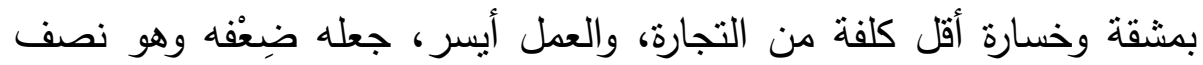

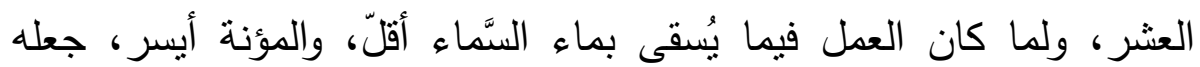

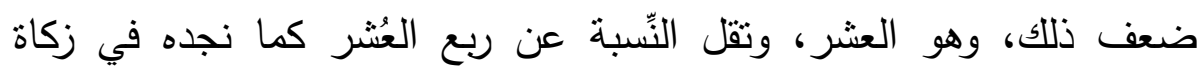

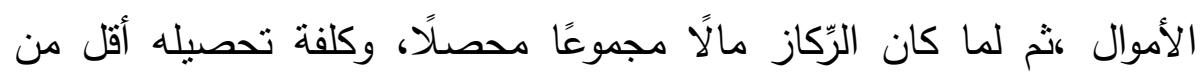

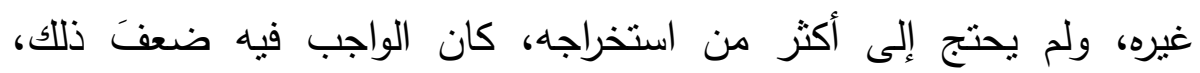

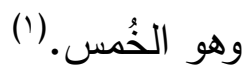

فهذا التَّاسب والثَّازن بدلّ على كمال الثَّريعة؛ لأنَّ المتأمل لما أوجبه

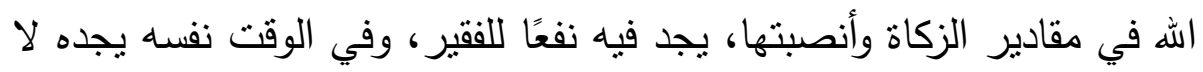
يضر الغنيّ.

لذللك قَََّّر الله سبحانه لكلّ مال يحتمل المواساة نصابًا محددًا لا تجب

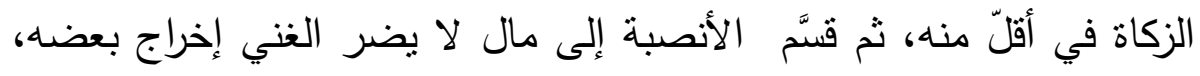

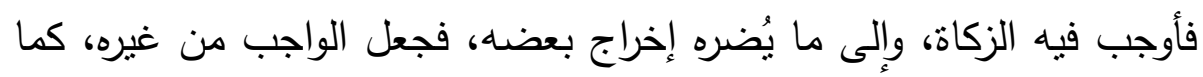

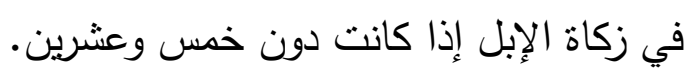
وكذللك أوجب الزكاة في أفضل الأجناس وأثنرفها وأعلاها، فأوجب زكاة ونداة

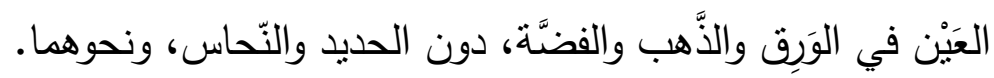

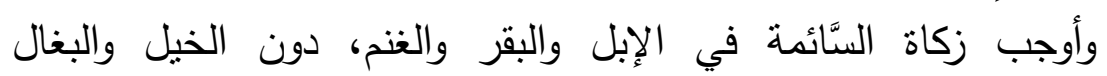

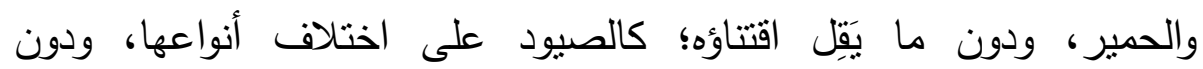

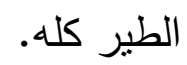

وأوجب زكاة الخارج من الأرض في الحبوب والثِّمار، دون البقول،

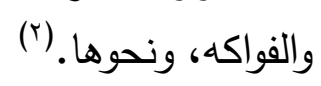

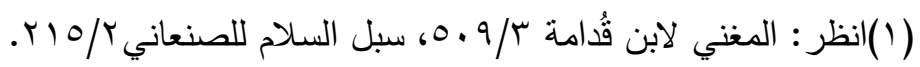

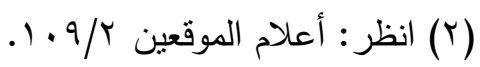


وقد توصَّل الخبراء إلى أنَّ الزكاة تقع في كل من الثروتنين النَّقدية والتجارية بنسبة r,0\%، وهو سعر مُعجز من حيث:

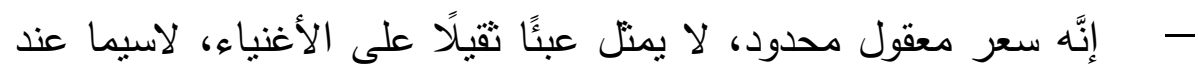

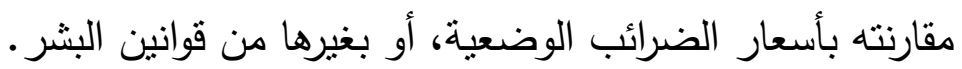

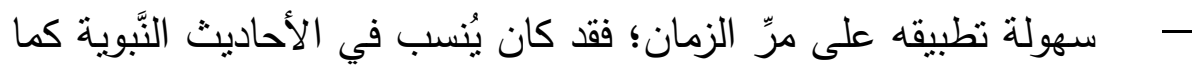

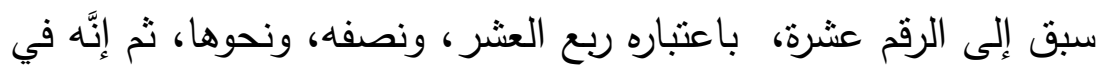

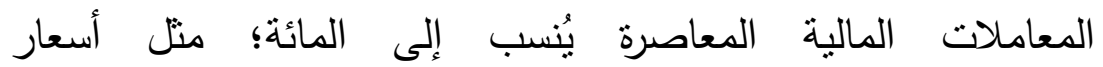

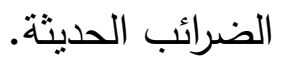

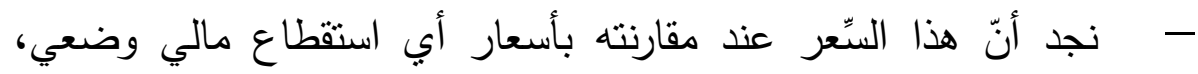

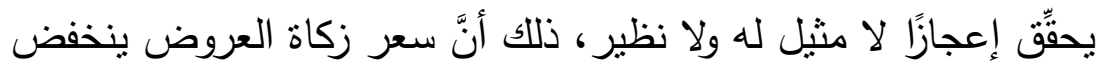

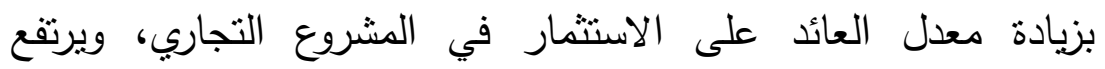

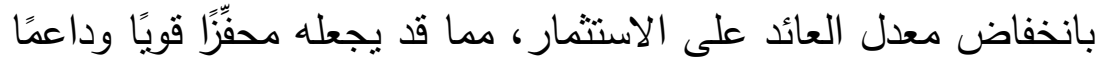

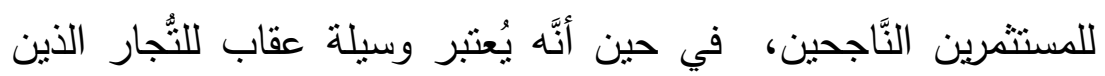

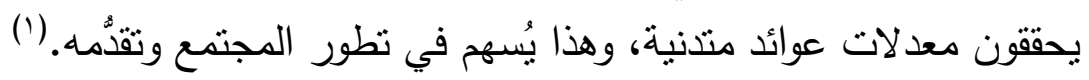

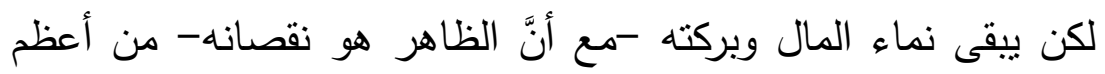
صور الإعجاز التنريعي في الزكاة، وفي نصوص الكتاب والسنة ما يؤيد ذللك،

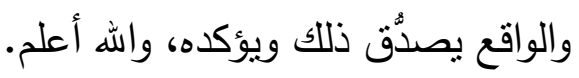

* $\quad * \quad * \quad * \quad * \quad *$

(1) (إعجاز تثريع الزكاة للاكتورة كوثر الأبجي صهمr. 


\section{الإلب النامس}

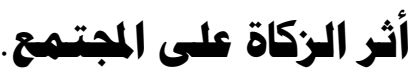

إنَّ الزكاة لها آثارُ عظيمة وفوائدُ عديدة تتعكس على المجتمع في الكثير

من المجالات، ومن ذلك:

\section{أولاً: المجال الاقتصادىى.}

- - - ميث تعتبر الزكاة موردًا دائمًا من موارد بيت المال في الإسلام. (') -

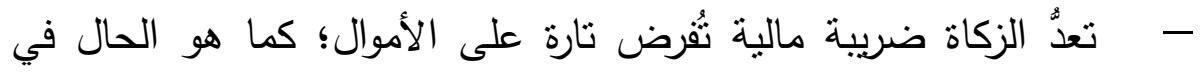
عامة الزكاة، وعلى الرؤوس تارة؛ كما في زكاة الفطر • - - تُُمي الزكاة الاقتصاد في الدول الإسلامية بصورة واسعة، فديننا يدعو الجميع للعمل؛ الغنيّ والفقير على السَّواء، فالفقير حين يأتيه المال يصبح عضوًا فعالًا في بناء المجتمع وتقدُّهه مع الغنيّ، وبذلك تزدهر الأُول الإسلامية، وتتقدَّم بنشاط صادراتها ووارداتها، وتكثر الخيرات،

$$
\text { وتعمّ البركات البلاد والعباد. (r) }
$$

- - - أنَّ في مشاركة الأغنياء لغيرهم من المحتاجين والفقراء حدًّا من تضخم الأموال عند الأغنياء، وعدم حصرها في طائفة محدودة من التّجار والأثرياء، أو أن تكون الأموال متثاولة فقط بين فئات معينة في المجتمع كالأغنياء ومن في حكمهم، فالزكاة في مضمونها عملية تتظيمية لسير

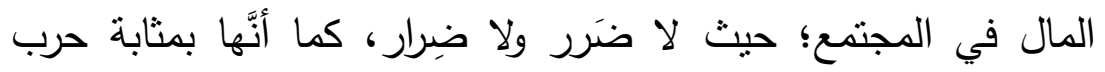

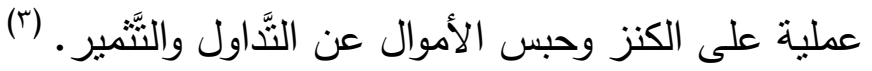

انظر: الزكاة للطيار صا111، نحو تطبيق معاصر لفريضة الزكاة لفؤاد العمر ص9 1.

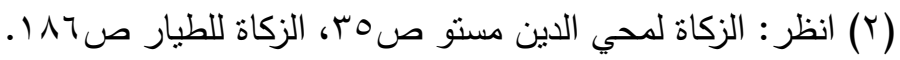

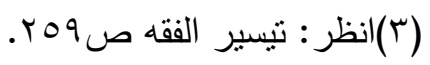


- - أنَّ في إخراج الزكاة منعًا للقحط والجَدب، وهذا يستفاد من قول النبي ئم

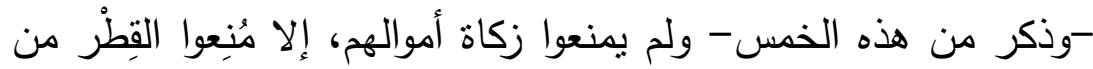

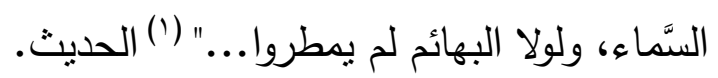

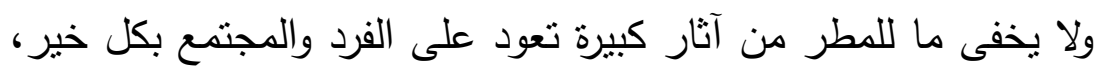

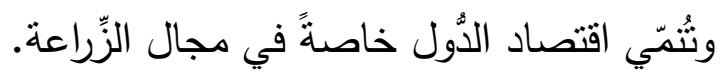

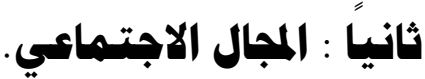

ويظهر ذلك من خلال الصور الآتية:

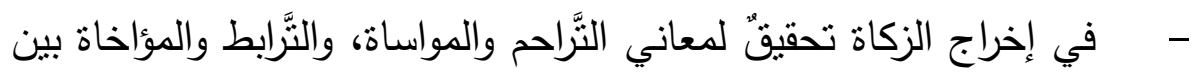

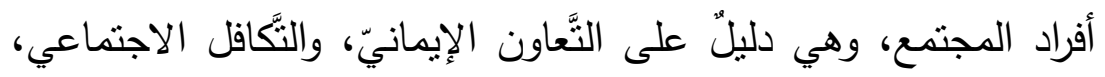

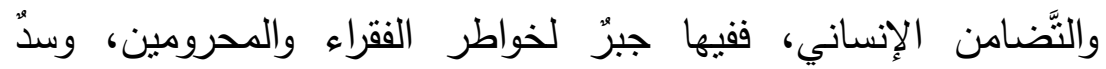
لحاجات البؤساء والمعوزين، فينشأ مجتمع الجسد الواحد المتين. (r) تقضي الزكاة على مكامن الكراهية والضَّغينة، وتُطفيء نار الحسد والحقد الأَّفينة في أنفس الفقراء والمحتاجين، حين يرون أخوانهم الأغنياء يمدون لهد يد العون والمساعدة، والإحسان والمعاضدة، فيرضون بما قسم الله

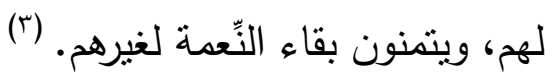
- - تعمل الزكاة على إقامة المصالح العامة للأمَّة، وذلك بتأمين وسائل العيش للمحتاجين، حينها تشعر الأسر المسلمة بالاستقرار والطمأنينة،

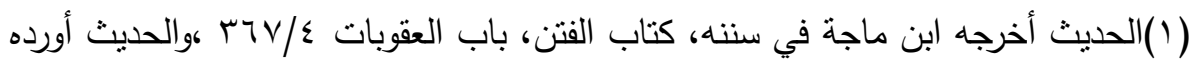

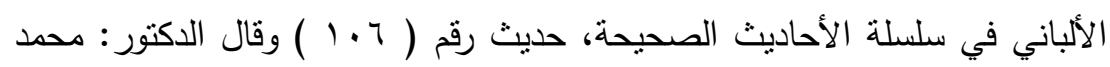

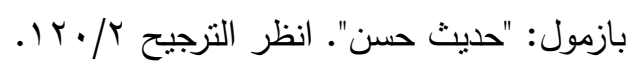

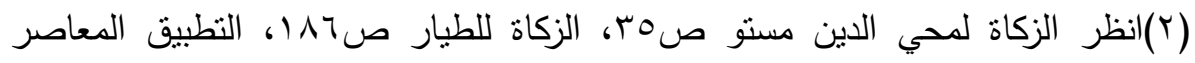

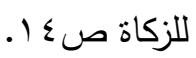

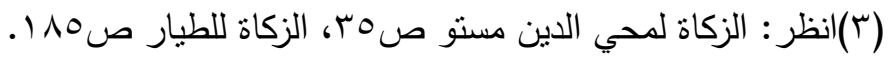




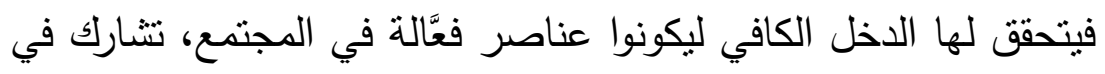

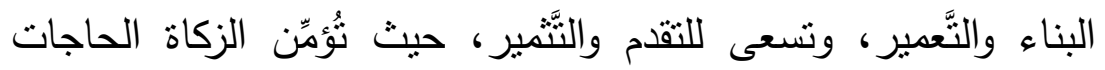

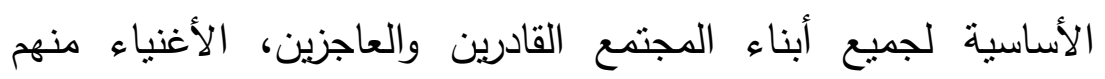

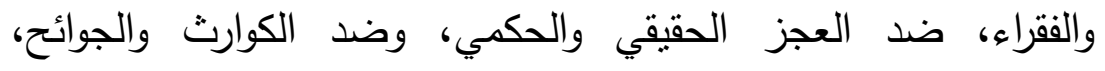



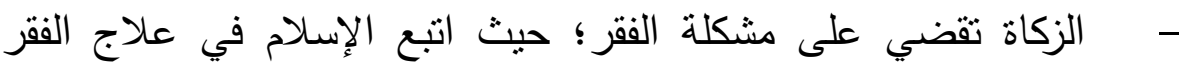

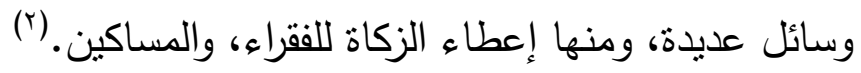

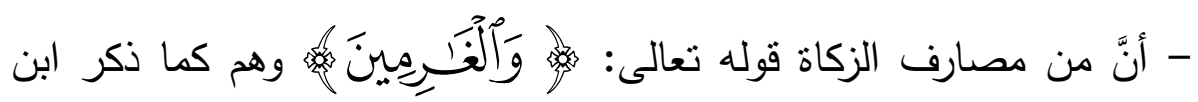
جرير الطبري وغيره : من استدانوا في غير معصية، ثم لم يجدوا ما

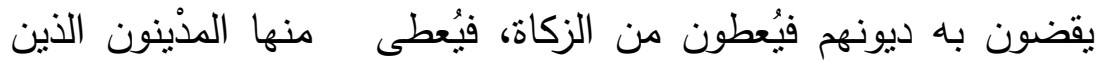

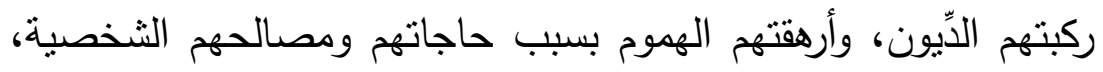

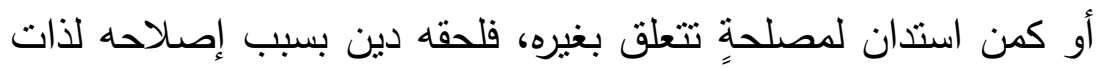

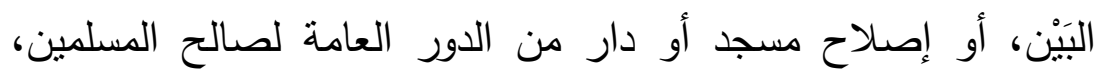

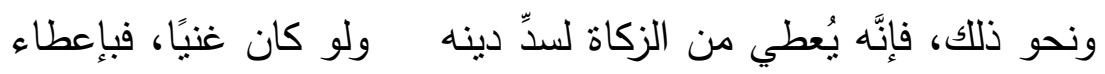

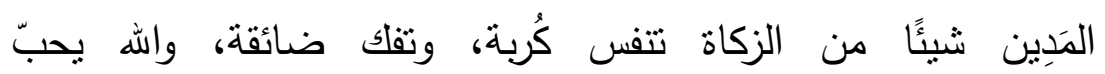
المحسنين. (r) -أنَّ من مصارف الزكاة إخراجها لابن السبيل، وهو المسافر سفرًا مباحًا،

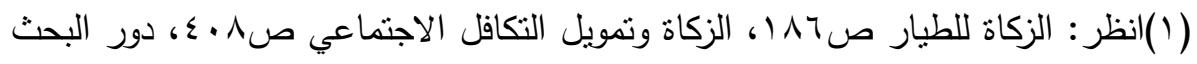

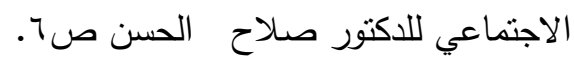

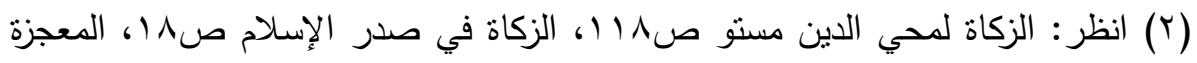

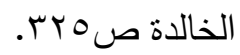

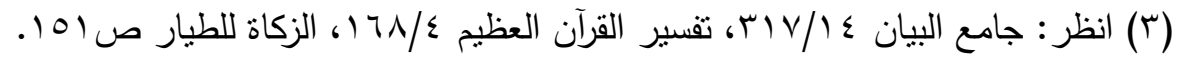

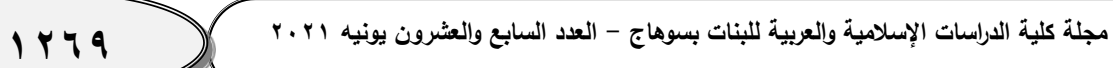




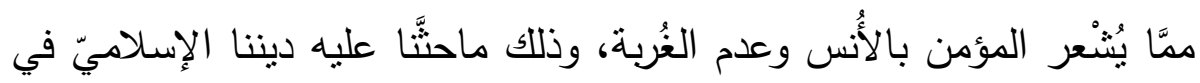

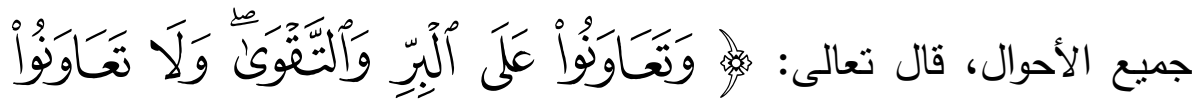

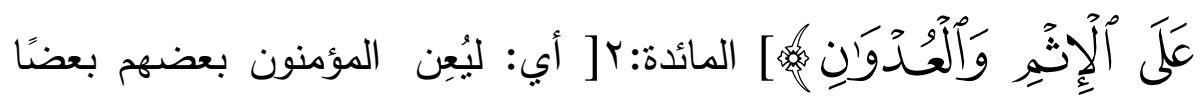

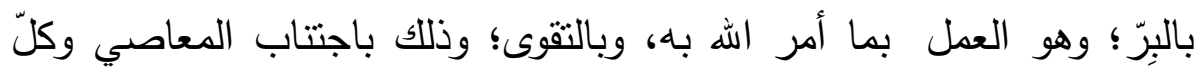

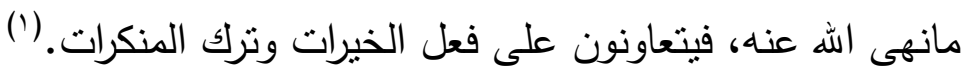
- أنَّ من مصارف الزكاة ما يُعطى للعاملين عليها، وفي ذللك سدّ للذَّرائع،

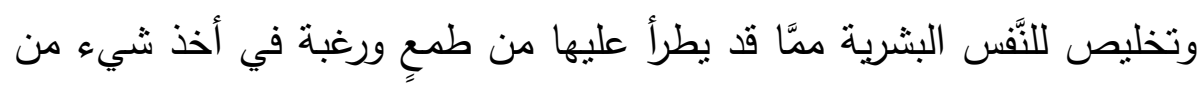
المال، خاصةً حين يراه كثيرًا، وقد يحميه أخذ نصيبه من الزكاة من تفكيره

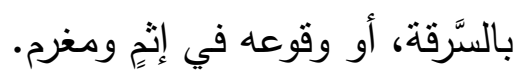

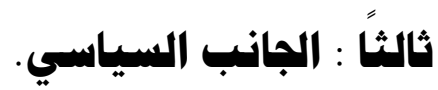
- أنَّ من مصارف الزكاة ما يُعطى للمجاهدين في سبيل اله قال تعالى:

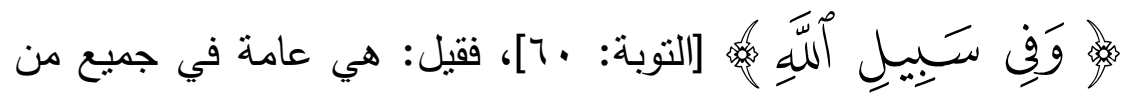
يخرج للجهاد في سبيل الله، فيُعطى المجاهدون كل ما يحتاجونه ثمنًا

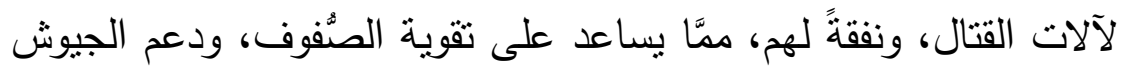

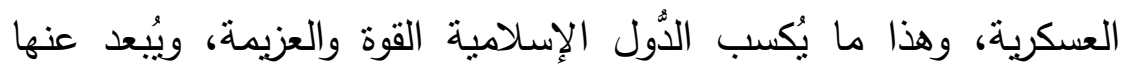

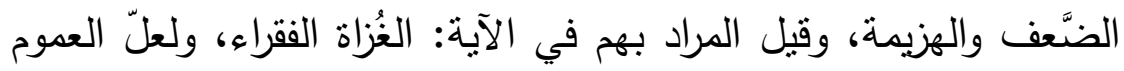

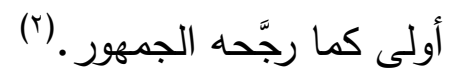

- أنَّ في إعطاء الزكاة لمن يدخل في الإسلام جديدًا تأليفًا لقلبه، وتعميقًا

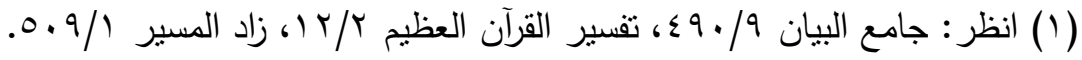

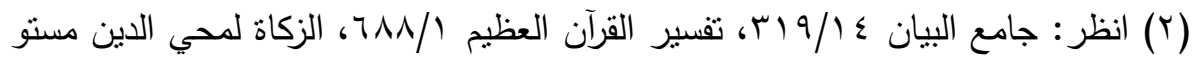
صז. 
لإِيمانه، ونتبيتًا لَقََمِه كما أنَّ ذلك يُرِغّب الغير في الإسلام، ويزيد عدد

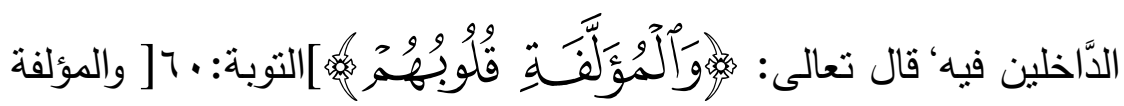

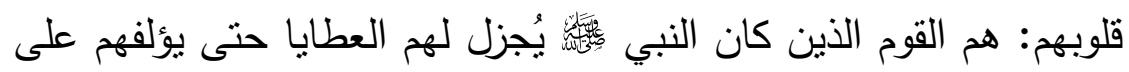
الإسلام، وكانوا ذوي مكانة وشرف، والمؤلفة قلوبهم قسمان: الأول: المؤمن؛ فيُعطى لينثبث على دين الله، ويحسُن إسلامه، أو يُعطى تأليفًا لقبيلته من المشركين حتى يُسلموا ، والقسم الثاني: الكافر المتعدي المؤذي؛ فيُعطى تألفًا حتى يكفّ أذاه عن المسلمين، أو حين يرون ميله

لالإسلام فيُعطى ليُسلم. (') إلى غير ذلك من الآثار والثَّمرات التي تتحقَّق بإخراج الزَّكاة.

* $\quad * \quad * \quad * \quad * \quad *$

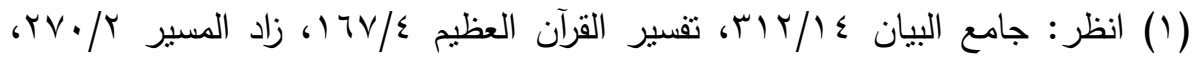
الزكاة لمحي الدين مستو صع صايان 


\section{الخاتهــــة}

أحمد الله تعالى على عظيم فضله وسابخ نعمائه، وأصلي وأسلم على الى الَّه

سيد عباده وخالص أصفيائه، محمد وعلى آله وأصحابه.

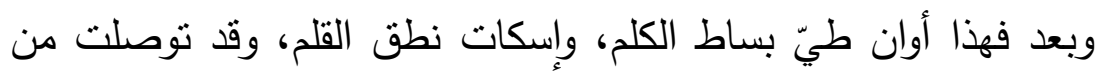

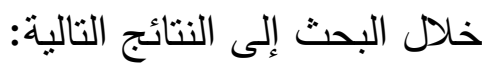

1- أنَّ الإعجاز التشريعي أحد وجوه الإعجاز في القرآن الكريم، وهذا يظهر

من خلال نصوص الكتاب والسنة.

r- أنَّ الإعجاز التشريعي يتمثل بما قامت عليه الثريعة الإسلامية من التهنية

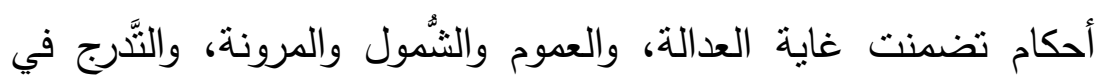

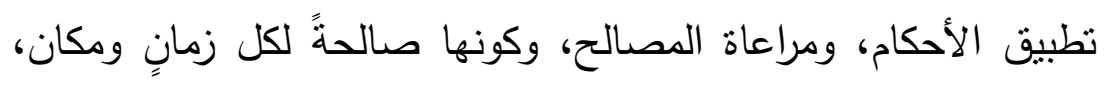

يظهر ذلك جليًا عند مقارنتها بالقوانين الوضعية.

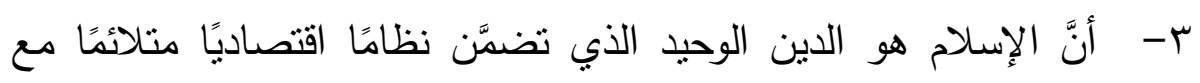

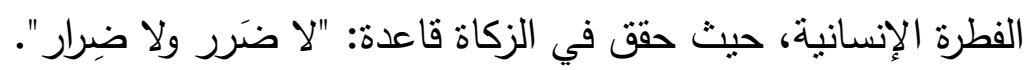

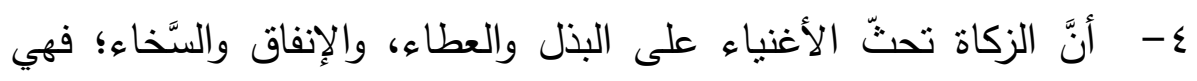

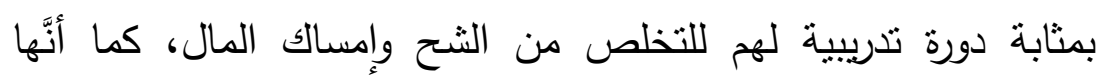
تقضي على الحسد والبغضاء في نفوس الفقراء، فهي تدعو إلى التعاون

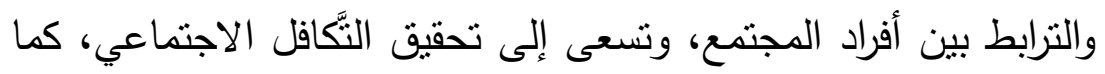

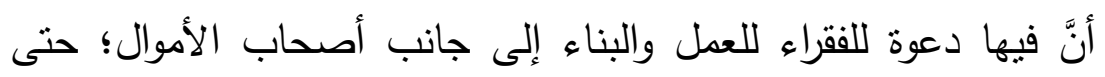

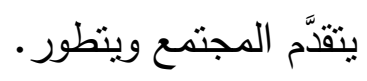

0- يظهر الإعجاز التشريعي في الزكاة في جنس الأموال التي فرضت فئها

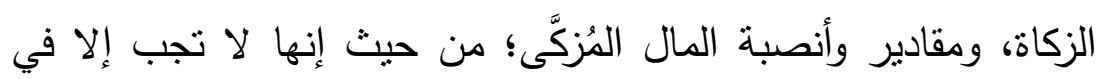

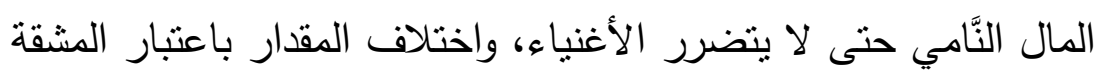

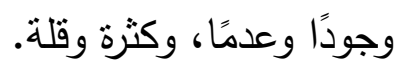


هذه بعض النتائج التي توصلت إليها - بتوفيق من الله وفضل - من خلال جهدي المتواضع.

وأقترح بأن نكون هناك عناية أكبر بالإعجاز التشربعي من حيث البحث والتمحيص والتأليف في موضوعات القرآن عمومًا، وموضوعات السور على بـ وجه الخصوص؛ حيث إن الحديث عنه في الكتب بُعدّ قطرة في بحر

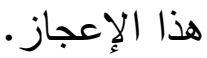

وأخيرًا أسأل الله العظيم، رب العرش الكربم، أن يجعل عملي خالصًا لوجهه الكريم، وينفعني به في الدارين، سبحان ربك رب العزة عما يصفون، وسلام على المرسلين، والحمد لله رب العالمين، والصلاة والسالام على النبي الأمين، وعلى آله وصحبه أجمعين.

* $\quad * \quad * \quad * \quad * \quad *$ 


\section{فهرس الصادر والمراجع}

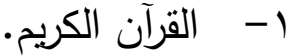

r- (الإعجاز التشريعي في الزكاة أوجهه ومعاييره ودلالاته الاجتماعية) أ.د رفعت السَّيد العوضي، المؤتمر العالمي الثامن للإعجاز العلمي في

القرآن والسنة.

r- ( إعجاز القرآن الكربم ) للاكتور فضل حسن عباس، وسناء فضل

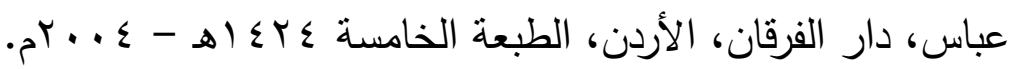
ع - ( إعجاز تشريع الزكاة في قواعد قياس الطاقة المالية وفي النصاب النقدي ) للاكتورة كوثز الأبجي، المؤتمر العالمي الثامن للإعجاز العلمي في القرآن والسنة.

- - ( إعلام الموقعين عن رب العالمين ) لأبي عبد اله محمد بن أبي بكر ابن القيم (ت VOr Vه) راجعه وعلق عليه طه عبد الرؤوف، طبعة دار

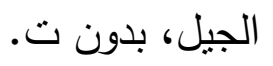

ד- ( البيان في إعجاز القرآن ) للدكتور صلاح عبد الفتاح الخالدي، دار

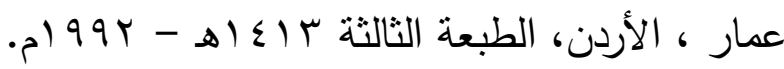

- - ( الترجيح في مسائل الصوم والزكاة ) لمحمد بن عمر بازمُول، دار

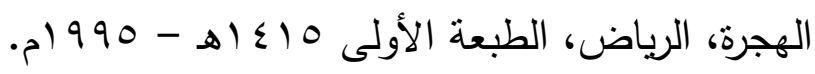

1- ( التطبيق المعاصر للزكاة ) للاكتور شوقي إسماعيل شحاته دار

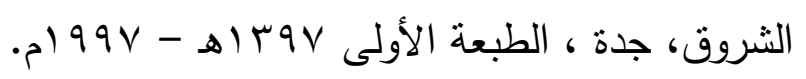

9- ( تقسير القرآن العظيم ) لأبي الفذاء إسماعيل بن عمر بن كثير

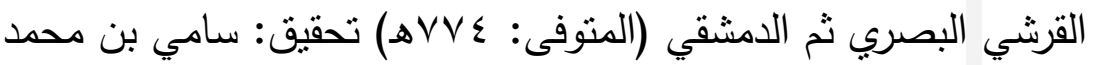

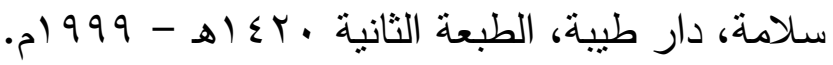


• 1- ( الجامع لأحكام القرآن ) لأعبد الله محمد بن أحمد بن أبي بكر بن فرح الأنصاري الخزرجي القرطبي (ت (TVه) تحقيق: أحمد البردوني وإبراهيم أطفيش، دار الكتب المصرية، القاهرة، الطبعة الثانية

$$
\text { . } 97 \varepsilon-81 \text { - ماك }
$$

1ا - ( جامع البيان في تأويل آي القرآن ) لمحمد بن جرير بن بزيد بن كثير

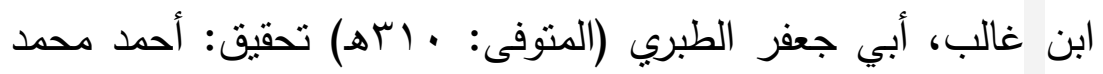

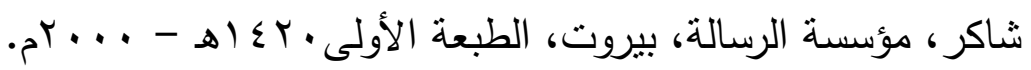
r ا- ( زاد المسير في علم التفسير ) لجمال الدين أبي الفرج عبد الرحمن بن علي بن محمد الجوزي (المتوفى: V9 Vهـ(كتحقيق: عبد الرزاق المهدي،

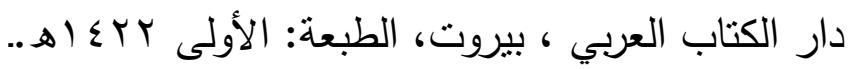
rا - ( الزكاة ) للدكتور عبد الله بن محمد الطيار، أشرفت على طباعته ونشره

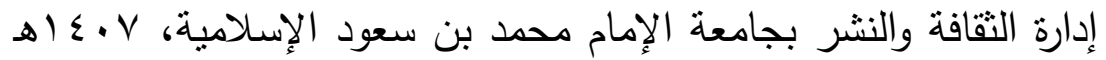

$$
\text { . } 19 \wedge \mathrm{V}-
$$

ع ا- ( الزكاة ) للدكتور محمد إسماعيل إبراهيم، دار الفكر العربي، القاهرة،

$$
\text { بدون ط. }
$$

1 - - (الزكاة فقها أسرارها ) لمحي الدين مستو، دار القلم، بيروت، الطبعة

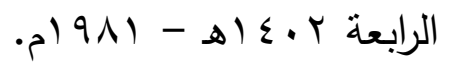

7 ا- ( الزكاة في صدر الإسلام ) للأستاذ الصادق ضوء النور ، المعه

$$
\text { العالي لعلوم الزكاة، السودان، ع ـ . بام. }
$$

V I ا - الزكاة وتمويل التكافل الاجتماعي) للاكتور ظافر إسحاق أنصاري، والدكتور محمود أحمد غازي، ضمن بحوث ومناقثنات الندوة التي عُقدت في عمّان، الأردن بعنوان: (الزكاة والتكافل الاجتماعي في الإسلام)

$$
\text { . } 99 \leq-81 \leqslant 10
$$


11- ( السنن الكبرى ) للإِمام أبي بكر أحمد بن الحسين بن علي البيهقي

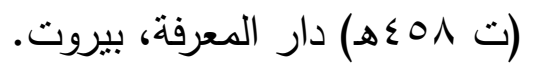

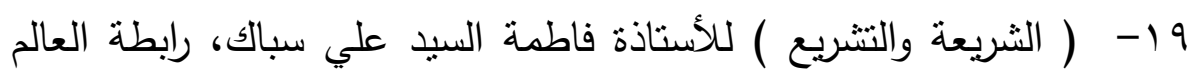

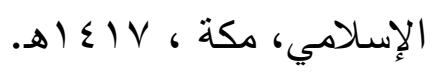

• ץ- ( الفقه الإسلامي وأدلته ) للاكتور وهبة الزحيلي، دار الفكر، بيروت،

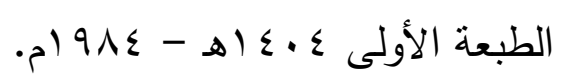

اب- ( المجموع شرح المهذب ) لمحي الدين بحيى بن شرف اله الدين النوبي

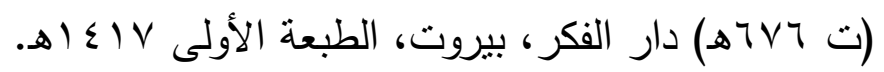

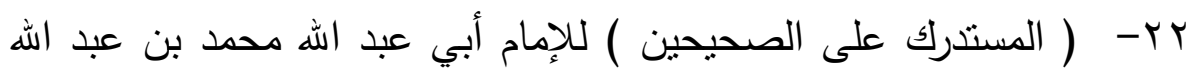

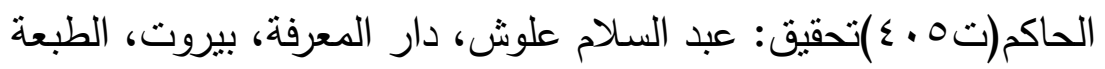

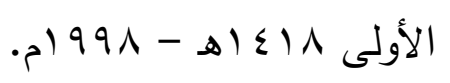

بr- ( المعجزة الخالدة ) لحسن ضياء الدين عِتُر، جميع الحقوق محفوظة

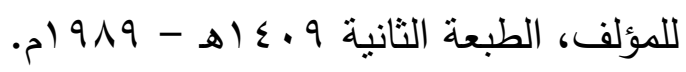

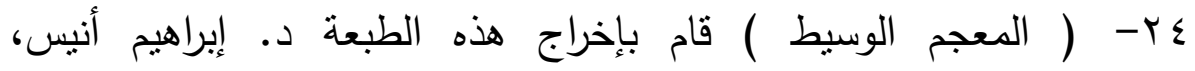



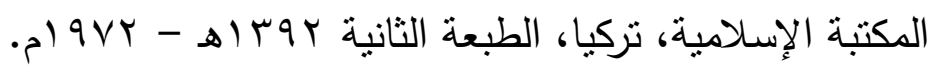

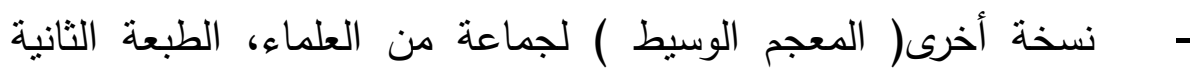

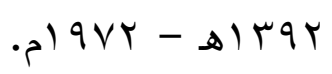

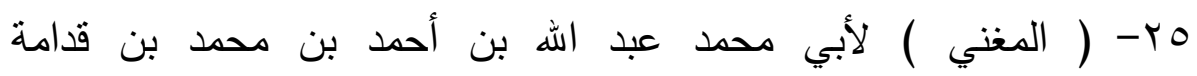

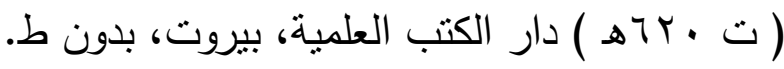

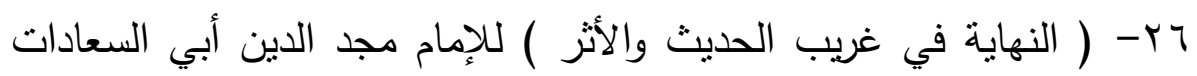

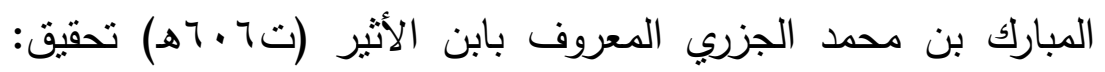

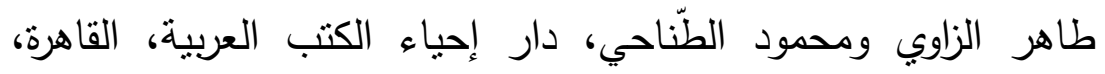
بدون ط. 
(أحكام الزكاة على ضوء المذاهب الأربعة) لعبداله ناصح علوان، دار

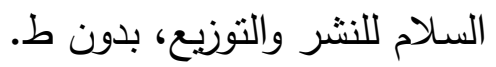

1ץ- ( تاريخ التشريع الإسلامي ) للثيخ محمد الخضري بك، دار القلم،

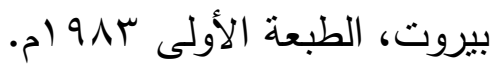

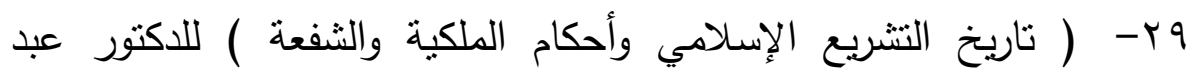

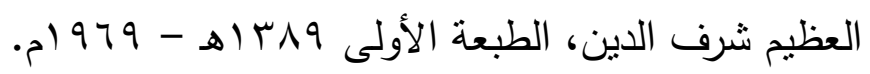
• r- ( تاريخ الفقه الإسلامي ) لمحمد علي السايس، مكتبة إحياء التراث الأل

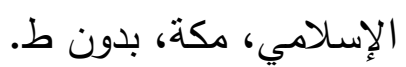
اسب- ( تاريخ المذاهب الإسلامية في السياسة والعقائد وتاريخ الدذاهب الفقهية

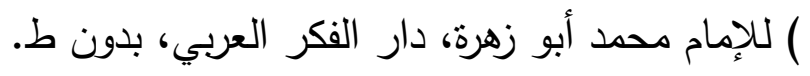

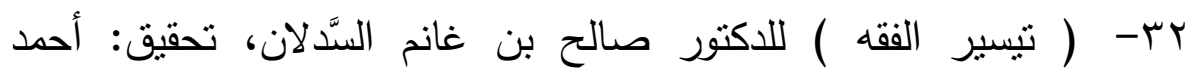

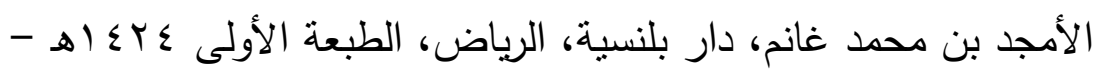

$$
\text { . }
$$

rr- ( دور البحث الاجتماعي في عمل ديوان الزكاة ) للاكتور صلاح

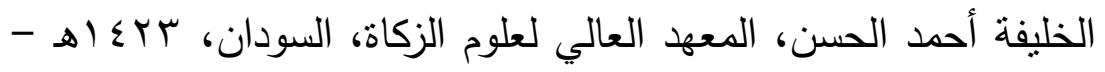

$$
\text { . }
$$

ع ז- ( زاد المعاد في هدي خير العباد ) لمحمد بن أبي بكر الزرعي ابن قيم

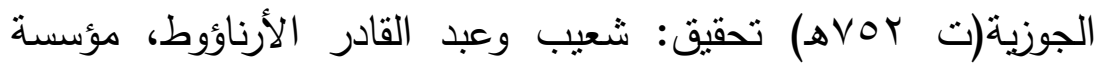

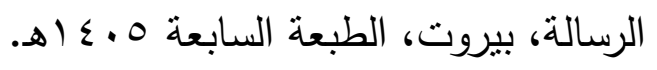

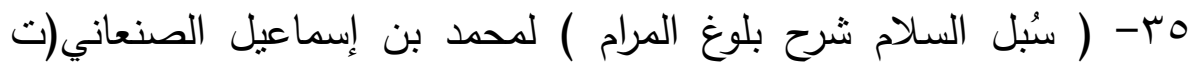

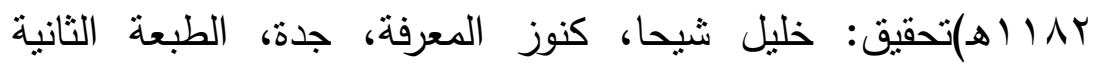

$$
\text { . } 1997-81 \leqslant 17
$$


بس- ( سلسلة الأحاديث الصحيحة ) للعلامة لمحمد ناصر الدين الألباني،

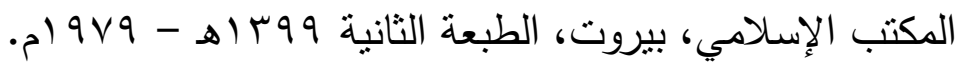

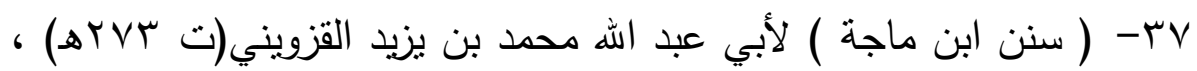
تحقيق: الثيخ خليل مأمون شِبْحَا، دار المعرفة، بيروت، الطبعة الأولى

$$
\text { . } 1997-81 \leqslant 17
$$

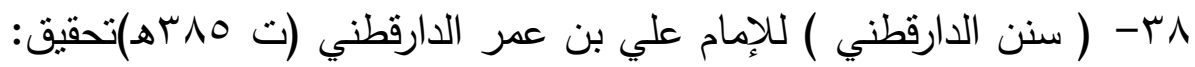
مجدي بن منصور الشوري، دار الكتب العلمية، بيروت، الطبعة الأولى

$$
\text { . } 1997-81 \leqslant 1 V
$$

qr- ( سنن أبي داود ) لأبي داود سليمان بن الأشعث بن إسحاق بن

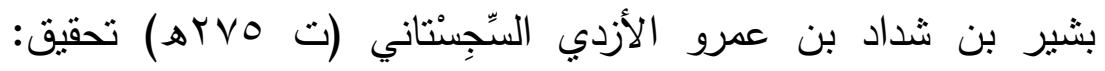

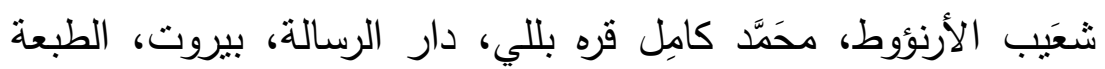

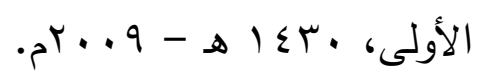

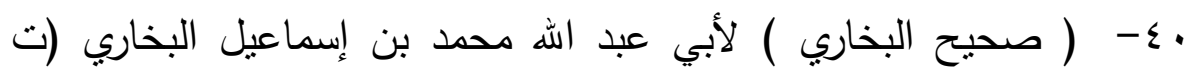
TOY Yه) تحقيق: محمد فؤاد عبد الباقي، ومحب الدين الخطيب، دار

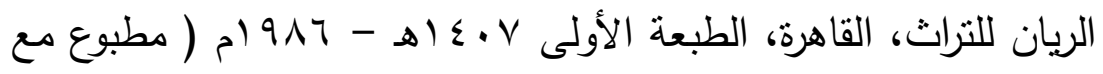

$$
\text { فتح الباري ). }
$$

اء- ( صحيح مسلم ) للإمام مسلم بن الحجاج النيسابوري (ت آبكه)

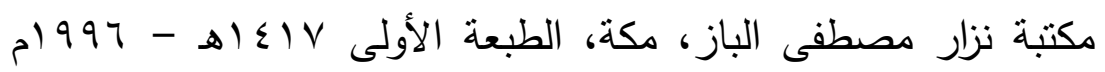

$$
\text { ( مطبوع مع شرح النووي ). }
$$

r؟- ( صحيح أبي داود ) لأبي عبد الرحمن محمد ناصر الدين بن الحاج نوح الألباني(ت .rی (هـ)، مؤسسة غراس للنشر والتوزيع، الكويت،

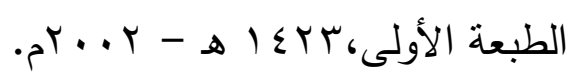


بـ- ( صحيح وضعيف سنن ابن ماجة ) لأبي عبد الرحمن محمد

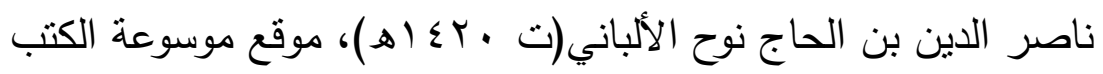
الثاملة.

؟ - - عامل الزمن في العبادات والمعاملات ) للاكتور محمد الطاهر الرزقي، مكتبة الرشد، الرباض، الطبعة الأولى ، بـ اهـ - . . . rم.

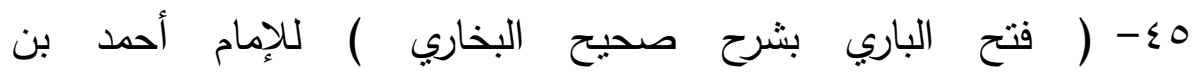
علي بن حجر العسقلاني(ت مO هـ) حققه: محمد عبد الباقي، ومحب

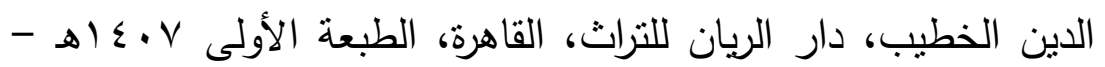
- ค) $9 \wedge 7$ جـ - ( لسان العرب ) للعلامة أبي الفضل محمد بن مكرم بن منظور الأفريقي

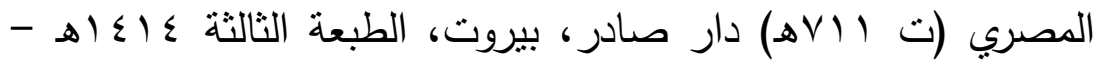
-p) $99 \varepsilon$

§V

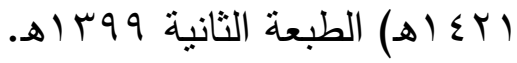

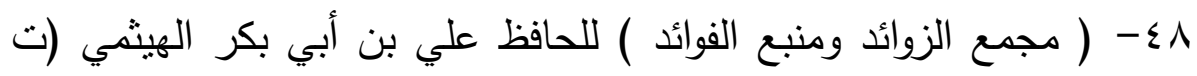

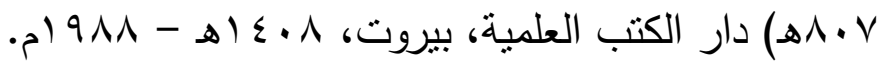

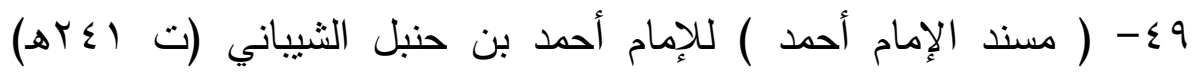
تحقيق: د. سمير المجذوب، المكتب الإسلامي، بيروت، الطبعة الأولى

$$
\text { . }
$$

•- - ( معجم مقاييس اللغة)لأحمد بن فارس بن زكريا القزويني الرازي، أبو الحسين (ت 90سه) تحقيق: عبد السلام محمد هارون دار الفكر،

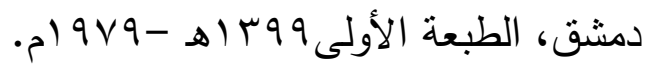


1- ( نحو تطبيق معاصر لفريضة الزكاة ) لفؤاد عبد الله العمر، ذات

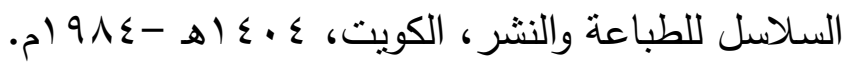

\section{المعاقع الإلكتزونية.}

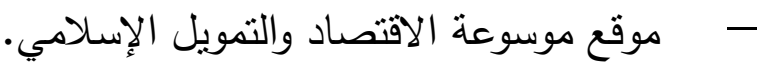

$$
\text { - - موقع الموسوعة الحرة. }
$$

- - موقع الموسوعة العربية العالمية.

- - موقع موسوعة الكتب الثاملة.

- - موقع الدرر السّنية.

* * * * * * * * 


\section{الإعجاز التشريعي في الزكاة}

فهرس المرضوعات

\begin{tabular}{|c|c|}
\hline الصفحة & الإوضوع \\
\hline IrT & | - المقدمة \\
\hline דצrו & تمهيد : التعريف بالإعجاز التتريعي \\
\hline ITM & |أهمية الإعجاز التشريعي \\
\hline q & الأسباب التي جعلت التشريع القرآني من أوجه إعجاز القرآن \\
\hline $1 Y \leq V$ & |أقوال الغرب في التشريع الإسـامي \\
\hline $1 r \leqslant 9$ & المطلب الأول: الإعجاز التشريعي في الزكاة \\
\hline I ror & المطلب الثاني: أثز الزكاة على الغني "المعطي \\
\hline IrT. & |المطلب الثالث: أثز الزكاة على الفقير "المتلقي \\
\hline 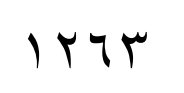 & المطلب الرابع: أثز الزكاة على المال \\
\hline IYTV & المطلب الخامس: أثز الزكاة على المجتمع \\
\hline ITVY & 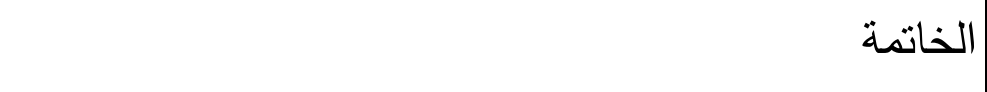 \\
\hline IYVE & |فهرس المصادر والمراجع \\
\hline$|r \wedge|$ & | فهرس الموضوعات \\
\hline
\end{tabular}

